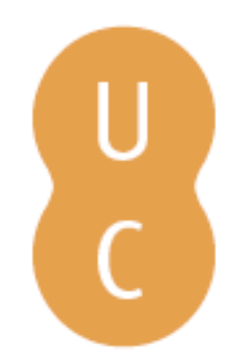

\title{
nombalina
}

\section{Representações de alteridade no teatro de Eurípides: o bárbaro e os seu mundo}

\author{
Autor(es): $\quad$ Silva, Maria de Fátima \\ Publicado por: Imprensa da Universidade de Coimbra \\ URL \\ persistente: URI:http://hdl.handle.net/10316.2/32392 \\ DOI: $\quad$ DOI:http://dx.doi.org/10.14195/978-989-26-0393-3_7 \\ Accessed : $\quad$ 26-Apr-2023 15:53:38
}

A navegação consulta e descarregamento dos títulos inseridos nas Bibliotecas Digitais UC Digitalis, UC Pombalina e UC Impactum, pressupõem a aceitação plena e sem reservas dos Termos e Condições de Uso destas Bibliotecas Digitais, disponíveis em https://digitalis.uc.pt/pt-pt/termos.

Conforme exposto nos referidos Termos e Condições de Uso, o descarregamento de títulos de acesso restrito requer uma licença válida de autorização devendo o utilizador aceder ao(s) documento(s) a partir de um endereço de IP da instituição detentora da supramencionada licença.

Ao utilizador é apenas permitido o descarregamento para uso pessoal, pelo que o emprego do(s) título(s) descarregado(s) para outro fim, designadamente comercial, carece de autorização do respetivo autor ou editor da obra.

Na medida em que todas as obras da UC Digitalis se encontram protegidas pelo Código do Direito de Autor e Direitos Conexos e demais legislação aplicável, toda a cópia, parcial ou total, deste documento, nos casos em que é legalmente admitida, deverá conter ou fazer-se acompanhar por este aviso.

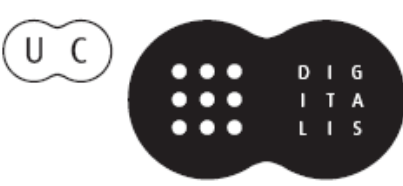




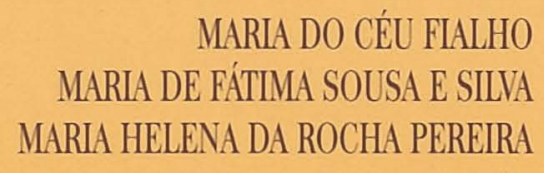

Coordenação

\section{Génese e consolidaç̃ão da ideia de Europa} Vol. I: de Homero ao fim da época clássica 
MARIA DO CÉU FIALHO

MARIA DE FÁTIMA SOUSA E SILVA

MARIA HELENA DA ROCHA PEREIRA

Coordenação

\section{Génese e consolidação da ideia de Europa}

Vol. I: de Homero an fim da época clíssica 


\title{
Coordenação editorial
}

Imprensa da Universidade de Coimbra

\section{Concepção gráfica}

António Barros

\section{Paginação}

Victor Hugo Fernandes

\section{Execução gráfica}

SerSilito - Maia

\section{ISBN}

972-8704-57-7

\section{Depósito Legal}

234088/05

(C) Outubro 2005, Imprensa da Universidade de Coimbra

\author{
Obra PUblicada COM O FINANCIAMENTO DE:
}

Centro de Estudos Clássicos e Humanísticos

$$
\text { FCT Fundaçāo para a Ciência e a Tecnologia }
$$

OBRA PUBLICADA COM O APOIO DE:

FCT: Fundação para a Ciência e Tecnologia - Ministério da Ciência e do Ensino Superior Apoio do Programa Operacional para a Ciência, Tecnologia, Inovação do III Quadro Comunitário de Apoio 

REPRESENTAÇÕES DE ALteridade No TEATRo DE EURípides:

O BÁRBARO E O SEU MUNDO

\author{
Maria de Fátima Silva \\ (Universidade de Coimbra)
}

Foi determinante o recontro político e militar que no início do séc. V a. C. contrapôs a Hélade e o oriente, para evidenciar, com riqueza de pormenores e repercussão de primeiro plano, o contraste antes sobretudo latente mas sempre conflituoso entre Gregos e os grupos humanos estranhos à sua cultura. Na pluralidade de manifestações que conheceu, a literatura da época registou a importância desta polémica com cores vigorosas e a tragédia em particular foi dela um poderoso porta-voz. Cambiantes diversas fixaram a convenção a que este quadro de oposições obedeceu. Foi, antes de mais, a língua a marcar a diferença e a distância; no critério helénico, o Bárbaro, ao mesmo tempo que articula sons que obedecem a uma cadeia incompreensível, realiza um processo mental que o distingue do Grego. Ao pensamento e respectiva expressão, seguem-se práticas e costumes distintos, que, na avaliação grega do 'outro', primam pela incivilidade ou selvajaria, que acarretam perigo e a incompatibilidade do convívio. Desconhecedor de regras como justiça, prudência, equilíbrio e hospitalidade, que constituíram desde sempre bases fundamentais na construção de um espírito europeu, o Bárbaro actua de uma forma grotesca, reservando a quem aporta ao seu território ou dele se aproxima animosidade, escravatura ou morte. São-lhe ainda naturais o despotismo no exercício do poder, como o exagero e o exibicionismo da riqueza e do luxo. A visão tradicional aponta, portanto, no sentido da radicalização de uma dicotomia, onde o Grego/Europeu 
representa o lado evoluído da humanidade, que já fez um progresso no sentido de um convívio humano cooperante e de uma organização cívica eficaz, em contraste com comunidades primitivas, situadas extra-fronteiras, que continuam condicionadas por comportamentos de natureza primária, próximos do bestial, onde apenas a necessidade de sobrevivência e a violência fazem lei. Porque, como muito bem acentua E. Hall ${ }^{(1)}$, reflectir sobre os Bárbaros sempre comportou um exercício de autodefinição, com base num contraste em que o retrato do Bárbaro pressupõe a determinação de um ideal de espírito grego.

É, no entanto, importante acentuar que já numa fase mais antiga a cultura grega fora sensível a este mesmo contraste com o 'outro', não ainda traduzido num conflito Grego-Bárbaro, mas expresso pelo paradigma mítico da luta aventurosa de um herói superior e obediente aos princípios de um código de arete contra um monstro, mais ou menos lendário que, nos seus traços animalescos e comportamentos mais ou menos brutais, representa o inimigo temível, situado num cenário de desconhecido e de perigosidade máxima. Ulisses ou Hércules são dois modelos inevitáveis deste tipo de herói arcaico, que o mito e depois a épica como sua expressão literária consignaram como vencedores de múltiplos trabalhos ou aventuras, onde o opositor é o 'estranho', porque desumano, selvagem e distante, numa perspectiva simbólica e indiferenciada.

Esta consciência da presença do 'outro' para além dos limites do mundo grego foi porém sofrendo sucessivos retoques e refinamentos, à medida que os vários movimentos da história fomentaram o encontro e o conhecimento mútuo. Deslocações migratórias da população grega em direcção a diversos territórios situados em toda a sua periferia, já a partir do séc. VIII a. C., como também os conflitos armados que se foram sucedendo, numa tentativa de definição de fronteiras ou de ocupação de territórios, permitiram que os Helenos fossem construindo do 'outro' uma imagem mais fiel e diferenciada. Em primeiro lugar, foi possível hierarquizar o desconhecido, distinguir povos e catalogá-los; depois conhecer-lhes os hábitos e poder, por um confronto permanente com os comportamentos gregos, determinar, com precisão cada vez maior, os termos da diferença. $\mathrm{O}$ 'outro' deixou então de ser o monstro lendário para se tornar no padrão de uma espécie humana diversificada, repartida em comunidades múltiplas, hierarquizáveis entre si, diferentes,

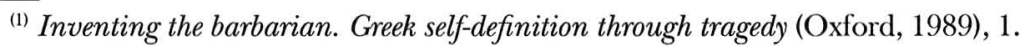


sobretudo nas práticas essenciais do quotidiano, do universo helénico. Uma nova convenção veio mesmo atribuir a cada grupo étnico um conjunto de traços permanente e identificativo.

Mas mais do que qualquer outra etapa histórica, o séc. V a. C. imprimiu a este longo processo uma evolução fundamental. Não foi impunemente que um grande conflito armado opôs a Grécia ao império do oriente, num desenrolar penoso de recontros políticos e militares extremos. A dimensão do conflito e o empenhamento que exigiu às duas partes envolvidas rasgaram, de forma até então desconhecida, as fronteiras entre os dois mundos. Duas mentalidades e culturas conheceram, no cenário das Guerras Pérsicas, a hora do cotejo e da competição. Bárbaro passou a ser algo de mais concreto, que a arte e a literatura da época puderam retratar em termos mais precisos. Nasce, neste tempo, o relato geográfico, etnográfico e histórico, em terreno iónico, a franja a separar as fronteiras dos dois espaços. Heródoto ocupa, para os modernos, um lugar determinante como testemunho vivo dos passos dados em direção a um mútuo conhecimento. Mas toda a expressão literária contemporânea, nomeadamente a dramática, dá à dicotomia grego-bárbaro um merecido relevo.

Eurípides é também, desta experiência, um testemunho fundamental. Na produção que dele conservamos podemos encontrar evidência para todas as cambiantes que a questão comportava e que animaram o debate entre os intelectuais contemporâneos do poeta. Já foi assinalado por aqueles que dedicaram a esta problemática em Eurípides a sua atenção ${ }^{(2)}$ que não é prioridade absoluta do tragediógrafo valer-se de traços concretos para delinear, com precisão realista, cada grupo não grego; a sua noção de 'estrangeiro' é mais geral, representada por um conjunto de elementos estereotipados, que sobretudo produzem com o modelo grego pontos de divergência e conflito. Várias são as perspectivas em que podemos distribuir os aspectos essenciais da questão na tragédia euripidiana. No Ciclope, está presente em termos satíricos a velha leitura mítica do herói de Ítaca em luta contra os monstros de um só olho, que habitam o ambiente estranho de uma ilha inóspita. Em muitas das tragédias, a avaliação do bárbaro exprime-se pela recorrência de traços convencionais: a caracterização das diversas comunidades não gregas em termos de espaço e seus habitantes; a concretização da diferença através de um conjunto de práticas consideradas relevantes para uma distinção entre

${ }^{(2)}$ Cf. D. Kovacs, The heroic muse (Baltimore, 1987), 82. 
a mentalidade grega e não grega; a utilização mais realista ou mais romanesca do tema do confronto e competição entre os dois hemisférios civilizacionais em que o mundo se divide; por fim, se a noção tradicional de uma hierarquia que assegura o ascendente do Heleno sobre o estrangeiro continua a vigorar em Eurípides, como expressão de um sentimento socialmente generalizado, não deixa o poeta de relativizar, numa época que é de crítica permanente a todos os valores tradicionais, o ascendente convencional, sugerindo, como outras vozes da época, que diferença não implica necessariamente vantagem ou desprimor, ou mesmo subvertendo os planos da dicotomia corrente.

Foi por certo ao mito consagrado à saga dos grandes heróis viajantes em luta contra monstros terríveis e sanguinários que Eurípides foi beber inspiração directa para as suas tragédias romanescas ou aventurosas, de que Ifigénia entre os Tauros e Helena são exemplos expressivos. Um conjunto de elementos convencionais comuns apoiam esta tese. Mas sobre a teia que suporta os dois modelos é visível o processo de actualização; não só se reconhece a inevitável conversão de um padrão narrativo em esquema dramático, o que se processa pela adaptação de um conjunto de moldes literários, mas sobretudo - aspecto relevante para o nosso objectivo - procede-se à transformação do contexto meramente fantástico num outro de natureza etnográfica. É curioso que, dentro da produção do tragediógrafo, seja Ulisses, o eterno aventureiro, que se informa em viva esticomitia com um Sileno prisioneiro do Ciclope Polifemo sobre o mundo a que o destino o fez aportar, a definir, com as perguntas que coloca, os traços convencionais no esboço do mundo bárbaro e no esquema de aventuras que proporciona a um Heleno ${ }^{(3)}$ : o desconhecimento e a evidente inacessibilidade do espaço (Cyc. 113-114), onde é patente a ausência ou diferença de um plano urbano ou arquitectónico (vv. 115-116; cf. Od. 9. 113-114, 182-186); a escassez e estranheza dos habitantes (vv. 116-118; cf. Od. 9. 187-189); a diferente organização social e política (vv. 119-120; cf. Od. 9. 112); os costumes novos em aspectos diversos, desde logo no que se refere aos hábitos alimentares (vv. 121-124); o desconhecimento de festas ou danças que exprimem um convívio e uma orgânica social colectiva (v. 124); a animosidade e selvajaria

(3) $\mathrm{O}$ conjunto de perguntas com que Ulisses pretende estabelecer um quadro da vida dos Ciclopes, que é paradigmático de um modelo bárbaro, obedece a critérios que Heródoto igualmente aplica no desenho de comunidades primitivas ou selvagens, nos seus capítulos etnográficos, nomeadamente o regime de vida sedentário ou nómada, o cultivo ou abandono dos campos, a dieta e o desconhecimento do vinho. 
habituais no contacto com estranhos (vv. 125-128); e ainda a substituição de uma actividade pacífica como a agricultura pela predilecção pela caça (vv. 121-122, 130).

O lugar onde a aventura decorre é o cenário conveniente a um episódio que deve exprimir distância, isolamento e exotismo em relação ao mundo conhecido. Já na criação mítica, essa paisagem é geralmente vizinha do mar e oferece ao visitante, como primeira barreira, uma costa rochosa e autodefensiva (Cyc. 20); adjectivos como agnostos e axeinos 'desconhecido' e 'inóspito’, fixaram-se para exprimir a falta de acolhimento que um tal espaço proporciona (IT 94, 125, 218). Pormenores da paisagem natural ou urbana ajudam na concretização específica de cada local, numa graduação que tem sempre o mundo grego por referência inevitável. A terra siciliana onde habitam os Ciclopes ${ }^{(4)}$, que configura a rudeza primitiva de um universo de monstros, não tem qualquer construção ou muralha defensiva (vv. 115-116) $)^{(5)}$ a protegê-la. Com frequência, uma paisagem pouco urbanizada rodeia-se da rudeza de uma floresta, em estado espontâneo, que oferece a imagem agressiva de um terreno nunca desbravado. É deste tipo a mancha que cerca

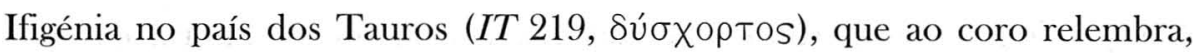

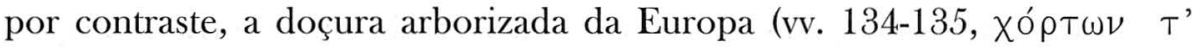
$\epsilon u ̉ \delta \epsilon ́ \nu \delta \rho \omega \nu$ Eủ $\rho \omega \dot{\pi} \pi \alpha \nu)$.

De acordo com as necessidades do próprio contexto dramático, pormenores identificativos do local podem ser valorizados, colocando ao mesmo tempo em evidência particularidades geográficas ${ }^{(6)}$ ou arquitectónicas

(4) Parece tendencial no séc. V a. C. a ideia de que os Ciclopes tinham habitado a Sicília: cf. Tucídides 6. 2. Também o ambiente rústico que caracteriza o cenário siciliano convém à natureza pastoral do drama satírico. Sobre a localização dos Ciclopes no drama euripidiano que deles recebe o nome, cf. V. Visa-Ondarçuhu, 'Le Cyclope d'Euripide ou la mise en scène de nouveaux espaces', Pallas 5 (2000), 61-79.

(5) Importa recordar os comentários de Tucídides sobre a evolução do mundo grego na senda do progresso e o lugar que nesse movimento ocupa a construção de muralhas e torres defensivas, que significa uma tomada de consciência do sentido de comunidade independente e de organização cívica: cf. 1. 7.

(6) R. Buxton, 'Iphigénie au bord de la mer', Pallas 38 (1992), 212, chama a atenção para o facto de o mar da Táuride, na costa norte do Mar Negro, considerado inóspito aos estrangeiros, ser frequentemente associado às Simplégades ou Rochas Cianeias (IT241, 260, 355, 1389). Mais significativo do que a localização exacta destes escolhos marinhos é, na opinião deste estudioso, o facto de eles funcionarem como uma espécie de emblema da barbárie táurica e de barreira a separá-la da Grécia, o mesmo é dizer do mundo civilizado. Antes de Eurípides, Heródoto é o testemunho mais expressivo sobre os Tauros (4. 99-103). 
indelevelmente associadas a um lugar ou comunidade étnica. Seguindo a sugestão do próprio poeta (IT 76), importa analisar com atenção os pormenores de cada ambiente. A existência de um antigo culto de Ártemis no país remoto dos Tauros implica que o templo da deusa seja a principal referência cénica na Ifigénia entre os Tauros, tanto mais que ao culto se liga, como sacerdotisa, a filha exilada de Agamémnon. O edifício avulta do cenário e é desde logo reconhecido por quem chega; apenas sinais de sangue sobre os altares e troféus humanos nas cornijas fazem do templo um emblema próprio de um povo sanguinário (IT 69-75) ${ }^{(7)}$, apesar, como as mulheres do coro não deixam de reconhecer, da beleza das suas colunas e do brilho dourado das suas cores (vv. 126-129). Há portanto, no caso do santuário de Ártemis entre os Tauros, uma confluência com a estrutura grega de um templo, que permite desde logo identificá-lo e reconhecer-lhe a harmonia arquitectónica. Mas qualquer expectativa de protecção divina é arredada pelos vestígios sangrentos de um culto bárbaro. Outros pormenores sobre o quotidiano dos Tauros são sugeridos: a pastorícia como sua ocupação rotineira (vv. 236 sqq.) e as cavernas nas rochas como sua habitação. A arqueologia veio, de resto, a abonar a veracidade destas informações.

Por seu lado, a peça que Eurípides dedicou a Helena decorre no Egipto, de que aos Gregos se impunha uma imagem de riqueza e de cultura superior, como o testemunha o relato extenso que preenche o Livro II de Heródoto. É através do Nilo, um ex libris do país que lhe deve a sobrevivência, que a heroína identifica o cenário (Hel. 1-3) deixando patente, pela menção das cheias que fertilizam os campos, uma ideia de abundância e de prosperidade. A mesma riqueza ressalta da morada régia, que impressiona Teucro pela majestade e opulência das suas proporções (vv. 68-70). A fama da sua grandeza permite ao navegante recém-chegado identificá-la espontaneamente. Nada denuncia, no caso do Egipto, qualquer sinal de ameaça ou de perigo. Pelo contrário, um pouco mais tarde, Menelau, também ele levado ao Egipto por acasos do destino e um pouco menos informado sobre o local que não reconhece (vv. 414-415), julga poder esperar de tão esplendorosa mansão um acolhimento generoso (vv. 430-433). Mas o ritmo aventureiro do episódio vivido por Menelau e Helena em terras longínquas requer a noção de perigo que a barbárie generosamente oferece. Passo a passo, o aparato egípcio vai-se denunciando como encobridor de ameaças, à primeira vista

\footnotetext{
(7) Sobre os sacrifícios humanos realizados pelos Tauros, cf. Heródoto 4. 103.
} 
ocultas, mas progressivamente mais sensíveis. A agressividade de uma velha serva do palácio, que acode ao chamamento de Menelau, previne-o contra um perigo fatal que destrói as esperanças do rei náufrago (vv. 437-440). Por fim, um mensageiro que corre no encalço do senhor de Esparta, em longa caminhada por terra de faraós, omite qualquer menção das grandezas do Egipto para se lamentar tão somente de um percurso difícil e arriscado por 'uma terra de bárbaros' (vv. 597-598).

É evidente, no que respeita à caracterização de um ambiente não helénico, que Eurípides, como um grego do seu tempo, pode estabelecer diferenças ou valer-se de referências que identificam em particular cada local. A agressividade primitiva e espontânea que o mito reservava a este tipo de paisagens cedeu lugar a um desenho mais concreto, susceptível de uma hierarquização em termos de beleza ou de sinais de civismo e prosperidade. Apesar de se não ter nunca perdido, mesmo assim, a noção tradicional de que o mundo não grego oferece riscos, mesmo quando à primeira vista se apresenta inofensivo ou até atraente ao visitante.

Do local, a atenção volta-se para os habitantes, também eles uniformemente 'bárbaros', o que significa, numa perspectiva geral, xenófobos e sanguinários. No plano mitológico, a agressividade tinha expressão imediata na natureza monstruosa e inumana dos moradores de paisagens remotas. Assim são também, em Eurípides, os residentes das regiões rochosas da Sicília, os filhos do deus do mar, gigantes de um só olho, que habitam antros solitários, 'esses assassinos de homens' (Cyc. 20-22). Neste enquadramento genérico de violência, a característica mais saliente é o desrespeito pela vida humana. Aos Ciclopes são aplicados sucessivos epítetos que concorrem para

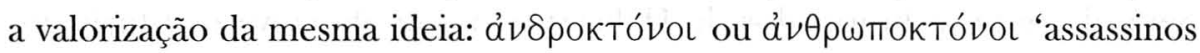

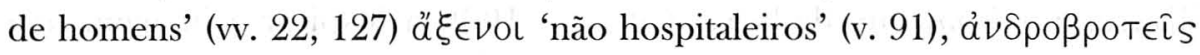
'antropófagos' (v. 93). E porque o contexto é o de um drama satírico, é mesmo permitido um gracejo que valoriza este que se considera o traço bárbaro por excelência; como um gourmet experiente, Polifemo não hesita em reconhecer a textura tenra da carne de um estrangeiro (v. 126), que tempera com a habilidade de um verdadeiro mestre de cozinha (vv. 241-246). À imagem primária de selvajaria, indissociável do espírito bárbaro como o Grego o delineava, subjaz o desconhecimento ou desrespeito por princípios de convívio humano, cujo estabelecimento corresponde a uma importante etapa do progresso social. A norma basilar que, na cultura grega, comanda a recepção devida a desconhecidos ou estrangeiros, a 
sagrada xenia ou hospitalidade, impõe a invulnerabilidade da vida humana e representa um comportamento fundamental de uma verdadeira civilização. Ao estrangeiro que aparece, sobretudo se em dificuldades e numa atitude de suplicante, é devido respeito máximo e acolhimento generoso e seguro. Este é um primeiro nomos fundamental, que só por si garante ao europeu um ascendente indiscutível. Os Ciclopes, como monstros desumanos que são, não conhecem sequer a lei ou depreciam-lhe o mérito (vv. 26, 30-31, 338-340). A súplica formal que lhes é dirigida por Ulisses e os companheiros deixa-os indiferentes, porque esse código nada diz à mentalidade bestial que os caracteriza (vv. 286-289, 369 sqq.). Convertem-se, por isso, no símbolo da completa anomia, a ausência total de observância da lei, de que a natureza de bestas medonhas que lhes é própria é por si justificação suficiente. Nas peças romanescas de Eurípides, o monstro ameaçador da tradição mítica é substituído pela perigosidade bárbara de povos longínquos e as práticas selvagens justificadas dentro da legitimidade de outros nomoi.

Ausente também da comunidade táurica, a lei da hospitalidade é incompatível com outras normas que aí vigoram, segundo as quais a vida de estrangeiros é destinada à imolação em honra de Ártemis (IT 280). Ou seja, a obrigatoriedade de sacrificar à deusa caçadora vidas humanas traduz uma divergência profunda, no plano religioso, entre o que se pode considerar um modelo de culto civilizado a par de um outro bárbaro. A expressão religiosa é um campo da vida colectiva onde diferenças de nomoi são patentes. Ao fazer a caracterização de diversos modelos culturais, através de um conjunto de pontos nevrálgicos da vida colectiva, também Heródoto tende a integrar como um topos permanente o culto e as regras a que obedece. Será, de resto, o historiador de Halicarnasso, que descreve os rituais dos Tauros no logos que dedica à Cítia (4. 103), a inspirar a imagem que Eurípides deles reproduz. O culto da deusa Ártemis não se isenta, também na Grécia, de sinais que apontam no sentido de uma violência latente (cf. IT 1446-1461). Gestos ou ritos simbólicos, que os cultos de Bráuron ou de Halas Arafénides incluíam, sugerem um passado a que talvez sacrifícios de vítimas humanas não fossem totalmente estranhos ${ }^{(8)}$. Mas o Grego da

(8) A Ártemis que os Gregos da época clássica conheciam e veneravam era uma deusa protectora da vegetação e da fecundidade da vida humana e animal. Era também seu atributo acompanhar o ciclo de vida desde o nascimento até à maturidade dos jovens, rapazes e raparigas. As oferendas votivas encontradas em Bráuron abonam exactamente este atributo da deusa como protectora da adolescência. Mas, para além deste lado benévolo, Ártemis teve sempre um outro 
época clássica rejeita o derramamento de sangue humano, que considera rito de bárbaros ou selvagens. Desse sentimento se faz porta-voz Ifigénia exilada entre os Tauros e forçada a executar um ritual que lhe repugna.

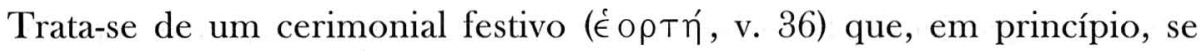
destina a agradar à divindade homenageada, e cuja tradição vem de longe (v. 38), sem que qualquer evolução no sentido de uma mudança para actos simbólicos ou vítimas alternativas se tenha verificado. Este conservadorismo, que carece de uma reflexão crítica à luz de outros valores que não entram no código de comportamento de um bárbaro, penaliza estrangeiros (v. 39), ou seja, evidencia simultaneamente uma atitude xenófoba e alheia à xenía. Dele participam, sem reticências, os habitantes do país dos Tauros. É com manifesto regozijo que o Boieiro vem anunciar, na pessoa de dois jovens gregos que acabam de aportar ao local, vítimas de eleição para um sacrifício. Na avaliação da oferenda, o raciocínio do pastor bárbaro segue escrupulosamente regras também respeitadas na Grécia: as vítimas são jovens, perfeitas e por isso propícias a uma imolação agradável à deusa (vv. 241-244). A tradição e a naturalidade com que esta regra sangrenta vem sendo praticada entre os Tauros tornou-se famosa, mesmo à distância, e constitui um traço identificador de um povo que simboliza uma barbárie profunda. Conhecem-no e temem-no os marinheiros vítimas de naufrágio (vv. 277-278). Repudiam-no aqueles que, mesmo sem se encontrarem na posição de vítimas, reflectem sobre ele segundo critérios mais civilizados. Ifigénia, a grega que o testemunha directamente, não pode deixar de o avaliar na perspectiva de alguém que pertence a uma religião onde a deusa Ártemis é também venerada, mas dentro de ritos de onde a violência foi sendo abolida ${ }^{(9)}$. Ao atribuir à própria deusa as subtilezas ou pormenores do rito (sophismata, v. 380), a filha de Agamémnon coloca-se diante de um

mais cruel, de divindade que liquida a vida, quer porque caçadora e guerreira, quer por exigir no seu culto sacrifícios de animais ou mesmo de seres humanos. Sobre os rituais inerentes ao culto grego de Ártemis, cf. P. Brulé, La fille d'Athènes (Paris, 1987); A. Henrichs, 'Human sacrifice in Greek religion: three case studies', in Le sacrifice dans l'Antiquité. Entretiens de la Fondation Hardt 27 (1981), 195-235; H. Lloyd-Jones, 'Artemis and Iphigeneia', JHS 103 (1983), 87-102.

(9) Não é possível omitir, no entanto, a ideia de que esta mesma Ifigénia foi condenada ao sacrifício no altar de Áulide, em terra grega, o que permite defender o paralelismo, encarecido por alguns comentadores, entre o ritual de Áulide que quase vitimava a filha de Agamémnon e o da Táuride, que quase lhe vitimava o filho, Orestes. A Ártemis de Áulide não se mostrou, portanto, menos sanguinária do que a sua versão táurica. Vide, sobre este assunto, K. V. Hartigan, 'Salvation via deceit: a new look at the Iphigeneia at Tauris', Eranos 84 (1986), 119-125. 
paradoxo. A mesma divindade que recusa como poluidor o contacto com o sangue ${ }^{(10)}$, parece aceitar com prazer sacrifícios humanos (vv. 380-384). Mas, continua Ifigénia, a incompatibilidade vai mais longe, porque não é admissível que deuses do panteão grego, dotados de uma majestade suprema como Zeus e Leto, tenham gerado uma deusa criminosa (vv. 385-386). Com esta observação, a filha de Agamémnon refere-se a uma religião pacífica e não estranha à ética, à qual actos sangrentos repugnam. Tal conquista passa por uma atitude de reflexão ou de aprendizagem que a versão táurica de Ártemis não experimentou ainda (amathia, v. 386) ${ }^{(11)}$. Mas ao espírito da sacerdotisa, como ao do próprio poeta, sobrevém a memória de versões tradicionais do mito grego, onde os deuses pareciam aceitar a oferta de carne humana; assim o caso de Tântalo, que presenteou os deuses, num banquete, com a carne dos próprios filhos para que a devorassem (vv. 386-388). Ifigénia não discute tal história, nem mesmo como eco de remotas práticas há muito eliminadas do convívio do seu povo; limita-se a recusá-las ou a desacreditá-las liminarmente. Mais do que verificar o carácter sangrento ou pacífico de um culto, a filha de Agamémnon pode interpretar o aparente paradoxo à luz de uma justificação etnográfica, com olhos de um grego do séc. V a. C. Os deuses e os respectivos cultos são tão só uma criação humana, em que cada povo projecta o seu próprio comportamento e cultura (vv. 389-390): 'Estou convencida de que esta gente de cá, sendo ela mesma sanguinária, atribui à deusa os seus próprios instintos selvagens'. Nessa perspectiva, a representante de um povo civilizado e norteado por um espírito humanista terá de se colocar numa posição inversa e projectar nos deuses a sua própria concepção de divindade (v. 391): 'Porque eu entendo que não há deuses malfazejos'. Encontrada para a divergência entre dois cultos uma justificação que assenta nos nomoi de dois povos, há que reconhecer que neste caso, onde violência ou pacifismo exprimem selvajaria ou civilização, a compatibilização ou simples tolerância entre as duas partes é inviável. Aos Gregos estas práticas repugnam visceralmente e só por força de um destino adverso lhes podem estar sujeitos (vv. 463-466). De alguma forma protegidos do barbarismo sanguinário pela repugnância que a sua cultura lhes impõe, alimentam o desejo veemente de se escaparem; apesar de executora de tais

${ }^{(10)}$ Como no caso de morte (cf. E., Alc. 22-23, Hipp. 1437-1439) ou de parto (E. El. 652-654, 1124-1126). Sobre a poluição no culto de Ártemis, vide Plut. Moralia 170b.

(11) Amathia, 'ignorância ou estupidez', é uma característica frequentemente associada com a barbárie (cf., e. g., Ar. Nu. 492). 
sacrifícios, Ifigénia demarca-se deles, numa atitude de crítica e contrição permanente (vv. 585-587) e anseia pelo regresso à pátria, que é ao mesmo tempo a libertação de um barbarismo imposto, mas repugnante (vv. 774-776). Este sentimento, antes de mais pessoal mas inspirado em normas em que o colectivo helénico se revê, é partilhado pelas mulheres gregas do coro, que saúdam com saudade a beleza elevada e tranquila do seu culto em contraste com a agressividade do rito bárbaro (vv. 221-228). E a própria deusa Ártemis não deixará de partilhar com as exiladas o júbilo do regresso, ao abandonar uma terra de bárbaros por Atenas, a cidade bem-aventurada que a aguarda (vv. 1086-1088). Estas são as linhas de força que fazem de Ifigénia entre os Tauros uma peça 'de salvação, redenção e restauração'(12); antes de mais dos herdeiros da casa real de Argos, os dois filhos de Agamémnon, Orestes que se vê livre da perseguição das Erínias, e Ifigénia que regressa ao mundo civilizado da Grécia, depois do exílio em terra bárbara e da experiência do sacrifício (como vítima e como executora); com os heróis, também as mulheres do coro escapam à barbárie e à escravidão; mas a redenção beneficia até os próprios deuses, Ártemis neste caso, que deixa os Tauros e as práticas primitivas do seu culto pelos templos mais acolhedores da Grécia $^{(13)}$. Com a missão de que encarrega Orestes - a de trazer da Táuride a estátua da deusa de volta à Ática - o deus de Delfos explica, no culto ateniense, os ritos de Ártemis, responsabilizando por aspectos mais violentos no seu cerimonial práticas antigas e estranhas.

Talvez porque mergulhadas num mundo distante e por isso mais atentas às diferenças cultuais, Ifigénia e as companheiras gregas não são também insensíveis à permeabilidade das suas tradições, como cidadãs da Hélade, a importações asiáticas. Esta consciência da interpenetração de culturas e de práticas faz parte do mesmo universo ideológico onde o 'Outro' se posicionou em relação ao Grego como uma presença permanente e concreta. Depois de, em sonhos, ter julgado perceber uma mensagem que lhe anunciava a morte de Orestes - o irmão, a promessa de continuidade de uma casa régia e quem sabe também o salvador de uma exilada -, Ifigénia prepara, em homenagem do suposto defunto, um ritual fúnebre que segue os trâmites do código grego. Embora em terra estranha, a filha de Agamémnon mantém a sua prática de homenagem aos mortos; no solo

${ }^{(12)}$ M. J. Cropp, Euripides. Iphigeneia in Tauris (Warminster, 2000), 31.

(13) Para M. J. Cropp, op. cit., 31, até o bárbaro Toas é apanhado nesta onda redentora, que o leva a abdicar da ira, perseguição e vingança contra os fugitivos. 
derrama as tradicionais libações de leite, vinho e mel (vv. 159-169; cf., e. g., Od. 10. 518-520; A. Pers. 607-615), enquanto dirige ao morto palavras de saudação e de saudade. Solidário com o sofrimento da princesa, o coro entoa cantos que reconhece como asiáticos (vv. 179-181), ainda que o ritual grego próprio dos mortos os tivesse já assimilado. O ritmo, como os brados agudos e emotivos que o acompanham, para além da própria designação desses cantos, espelham uma origem estrangeira, aceite pelos Gregos na sua exuberância como adequada a um rito por natureza excessivo ${ }^{(14)}$.

A selvajaria e o desrespeito pela hospitalidade que, no país dos Tauros, têm repercussão evidente no culto, ganha no Egipto outra dimensão. Uma primeira abordagem do universo onde se encontra também exilada uma grega, desta vez Helena de Esparta, dimensiona o Egipto como um território não helénico, naturalmente, mas que partilha com o mundo civilizado alguns traços fundamentais, que têm, na peça dedicada a Helena, uma expressão bastante pessoalizada. Por tradição - encarnada em Proteu, o monarca anterior, já falecido - a piedade diante dos deuses reina em terras do Nilo. O nome que o velho monarca encontrou para o seu sucessor, Teoclímeno, espelha a veneração pelo divino que lhe norteou toda a vida (Hel. 9-10); e mesmo se o nome dado à filha foi inicialmente Eidô, a designação que mais tarde a substituiu de Teónoe assentou com propriedade numa profetisa que dedicou ao culto divino todo o seu talento espiritual (vv. 10-15). A mesma piedade para com os deuses parece acarretar respeito equivalente para com os homens; o próprio Zeus o reconheceu quando elegeu Proteu, 'o mais piedoso dos mortais', como o protector seguro da virtude de Helena no exílio (vv. 46-48). Portanto, o quadro que o prólogo da peça estabelece retrata o Egipto como uma comunidade 'outra', mas cumpridora de leis civilizadas, nomeadamente em matéria religiosa e da xenía devida aos estrangeiros. Este é um outro nível de bárbaro, que exprime sobretudo o não grego sem uma carga forçosa de violência. $\mathrm{O}$ curso aventuroso da intriga, porém, exige que o Menelau salvador da sua dama encontre no Egipto ameaças e perigos, como grego que é, mas também como marido de Helena e rival dos múltiplos apaixonados da beldade espartana. O que significa que, quando a ameaça

${ }^{(14)}$ A popularidade desta exuberância levou a que legisladores, como Sólon (cf. Plut., Solon 12. 8), tivessem tentado pôr cobro ao exagero e insistido numa maior moderação e decoro neste tipo de cerimónias. Assim o exigia a natural sobriedade grega posta perante extremos denunciadores de uma influência bárbara. Cf. ainda Heródoto 6. 58. Sobre o carácter bárbaro dos trenos entoados pelos coros de tragédia, vide E. Hall, op. cit., 115-116. 
- convencional em terra de bárbaros - se revela também neste caso, não se coaduna bem com a prática comum e a imagem exterior do Egipto, como terra onde faz lei o civismo e o acolhimento de visitantes. Tem de ser para o facto encontrada uma explicação pessoal e de alcance passageiro ${ }^{(15)}$. Helena conhece esse perigo e avisa dele Teucro, o primeiro grego da peça a pisar terras do faraó. $\mathrm{O}$ caso coloca-se no plano da perseguição desencadeada por Teoclímeno, o monarca actual, contra qualquer grego que chegue ao seu país; de uma forma gratuita, o estrangeiro é simplesmente liquidado e a causa, que por enquanto é silenciada, nada tem a ver com um nomos colectivo e com a aplicação de uma prática tradicional (vv. 151-157). Experiência semelhante acompanhada do correspondente aviso será vivida adiante por Menelau, face à escrava que acorre à porta do palácio; também o rei de Esparta é prevenido de que os Gregos não são ali bem-vindos e de que a sua vida corre perigo (vv. 439-440, 443-444). Mas os motivos são, desta vez, explicitados: a fúria ameaçadora é pessoal, de Teoclímeno, e tem um alvo exclusivo, os Gregos

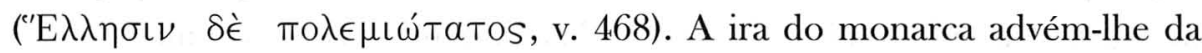
(irracionalidade da paixão, que é comum na natureza bárbara, e que partilha com uma Medeia, por exemplo ${ }^{(16)}$. O estímulo para os excessos que comete são de foro sexual, o desejo irracional e físico da bela Helena. Esta mesma noção de que o machismo bárbaro constitui uma ameaça para as mulheres gregas está patente no discurso que Ifigénia faz em Áulide, na iminência da morte, enunciando a protecção das suas compatriotas contra a violação bárbara como um dos lados da causa que defende (IA 1380-1381). Como também os motivos verdadeiros da ameaça egípcia são agora esclarecidos e resultam da presença de Helena no palácio; o problema é, portanto, pontual (v. 479) e não colhe a adesão de um povo, porque a própria serva quer demarcar-se dessa atitude persecutória e declarar a sua simpatia pelos Gregos (v. 481). É patente que Menelau não está sob uma ameaça peremptória como aquela que atemorizava todo e qualquer navegante à aproximação da costa táurica. Parece-lhe até estranho, em terra de tal opulência, que a xenia não seja regra praticada e que se recuse ao viajante perdido um naco de pão, o que é uma atitude bárbara por excelência (vv. 501-502). Espera mesmo que o seu nome lhe valha alguma compreensão, o que coloca o relacionamento

${ }^{(15)}$ Há todavia outros testemunhos literários que denunciam a imagem grega dos Egípcios como comportando malícia, traição e falsidade: cf. Cratin. fr. 406 K.-A.; Hyp. 3. 3, 13, 23; A. fr. 373.

(16) Vide infra, p. 220. 
da Grécia com o Egipto ao nível de uma relativa proximidade. É evidente, também do testemunho de Heródoto, que o conhecimento que os Gregos tinham do Egipto era profundo, o seu relacionamento existente desde pelo menos o séc. VI a. C., e que a grandeza do país dos faraós não deixou de impressionar favoravelmente o povo da Hélade. Barbárie obedece, no caso egípcio, a uma outra graduação e resulta mais das exigências de uma convenção dramática do que da própria realidade etnográfica.

Logo, para que a trama aventureira da convenção se cumpra, por obra dos amores ciumentos de Teoclímeno o Egipto, como cenário da aç̧ão, converte-se em 'país de bárbaros' (v. 600). Nele espreitam os perigos que, como sempre, ameaçam a vida de estranhos (vv. 863-864) e que pressupõem um processo de salvação que se consuma pela fuga e pelo afastamento (v. 743). Mas a aventura egípcia vai resultar não só no regresso dos fugitivos à pátria e à normal monotonia da existência, como também no regresso do Egipto à sua condição de terra justa e hospitaleira. Tal será possível, mau grado a autoridade violenta de Teoclímeno, através da intervenção pacificadora de Teónoe, ela afinal a verdadeira herdeira da tradição de justiça e generosidade legada pelo velho Proteu (vv. 999-1004).

Assim definida a natureza bárbara dentro de um conjunto de traços abrangente, de onde avulta a impiedade, o desrespeito pela vida humana e a sua eliminação impiedosa, como ainda a ausência de lei, outros comportamentos ou nomoi foram sendo acrescentados ao retrato à medida que um contacto mais próximo deles deu ao grego uma noção exacta. A ordem social é um elemento relevante, que veio trazer ao contraste Grego/Bárbaro um sentido político. O próprio mito acolheu este ponto de vista, que tem a democracia clássica como pano de fundo. Assim, no Ciclope (vv. 119-120), Ulisses pode inquirir do Sileno a propósito do regime em vigor no reino dos míticos filhos de Posídon: 'Quem os dirige? Estão sujeitos a um poder democrático?’ Para ouvir como resposta: 'São nómadas. Ninguém deve obediência a ninguém'. O que significa que o 'monstro' ou o avesso do homem civilizado vive em plena anarquia, sem chefe nem estrutura política, desconhecendo mesmo as bases do seu fundamento que se exprimem na existência de uma pólis ${ }^{(17)}$. A cidade não existe, nem como

${ }^{(17)}$ A falta de um sentido social entre a espécie humana, de que o aglomerado habitacional é símbolo, exprime com frequência a ausência de uma civilização ou o atraso no desenvolvimento e no progresso; experimentaram-na, segundo Tucídides, os próprios Gregos nos tempos remotos da sua história (1. 2); mas a mesma carência é capaz de sugerir a barbárie mais primitiva, como a 
aglomerado construído nem como sociedade organizada. O nomadismo funciona como o oposto desse normal processo em vigor na Grécia clássica e significa a errância própria de um estádio primitivo de civilização, que impõe como regras de vida a auto-sobrevivência e a desprotecção próprias de um individualismo total.

Mas ultrapassado o estádio de uma selvajaria primária, que prima pela anarquia, a tendência das comunidades humanas é para se organizarem sob uma autoridade monárquica ou mesmo tirânica ${ }^{(18)}$. É este o modelo em vigor entre os Tauros, 'onde um rei bárbaro reina sobre bárbaros' (IT 31), o mesmo é dizer, onde um povo tolera a autoridade arbitrária e prepotente de Toas; como também no Egipto, onde um rei justo e piedoso, Proteu, estendia uma autoridade firme a todo o território (Hel. 4-5). Pode, por isso, Helena generalizar com base na sua experiência (v. 276): 'Os bárbaros, à excepção de um único, são todos escravos'. Com uma frase de ritmo proverbial, a rainha de Esparta exprimia a crença grega de que os bárbaros são, sem excepção, servos de um tirano, o seu rei ${ }^{(19)}$.

Ao modelo anárquico mais primitivo corresponde também o abandono dos campos, que não são cultivados (cf. Od. 9. 108), e uma dieta alimentar que se satisfaz dos produtos espontâneos da natureza (Cyc. 121-122, cf. Od. 9. 219-223). O vinho, que é sinal de civilização e de requinte, é desconhecido das comunidades mais primitivas (Cyc. 123-124, cf. Od. 9. 297). Por fim, as festas, que constituem ocasião de convívio e de participação de todos na vida comunitária, assinalando momentos relevantes na experiência comum, estão ausentes de grupos étnicos onde uma estrutura social não existe ou é marcada por uma completa desumanização. Como fiel devoto de Dioniso, o Sileno no exílio relembra com amargura o som festivo dos evoés em honra de Baco, que pertencia à vida civilizada de que se encontra afastado (Cyc. 25). O coro dos Sátiros que o acompanha na distância da Sicília evoca a festa báquica, em todos os seus pormenores: o erguer dos tirsos, o som dos tamboretes, as goladas de vinho, os cantos e as danças festivos (vv. 63-75), com a nostalgia de quem recorda um prazer remoto e perdido. Em troca

que os Ciclopes representam na Odisseia (cf. 9. 113-114), ou os Citas nas Histórias de Heródoto (4. 46). O historiador das Guerras Pérsicas, porém, na visão que tem desapaixonada ou mesmo elogiosa dos costumes bárbaros, vê no nomadismo dos Citas uma descoberta genial para evitar invasões e para se acautelar de qualquer ocupação inimiga.

(18) O mesmo entendimento é expresso por Tucídides em 1. 4, 8-9, 13.

${ }^{(19)}$ Cf. afirmações semelhantes em E. Andr. 664-666, Tr. 933, IA 1400-1401. 
da festa dionisíaca, o mundo bárbaro dos Ciclopes nada tem para oferecer (v. 124).

Esvaziado de prazeres e recheado de perigos, o além fronteiras pressupõe sempre aventuras arriscadas. $\mathrm{O}$ viajante está consciente do perigo, que prevê grande e traiçoeiro, como da fraqueza da sua posição de exilado, de náufrago ou de simples caminhante perdido nas rotas do desconhecido (cf. Cyc. 85-93, 108-109, IT 479-481). De facto, o destino que a terra bárbara lhe reserva é sempre um calvário doloroso de penas. Se consegue escapar com vida às ameaças de assassínio ou de sacrifício ritual, está-lhe aberta uma existência de servidão. Em terra de Ciclopes, o Sileno é escravo (vv. 23-26), condenado a executar tarefas servis, a pastorícia ou os trabalhos domésticos (vv. 27-31, 76-81). Entre os Tauros, Ifigénia serve no templo de Ártemis, sujeita à bárbara tarefa de executar estrangeiros mau grado a repugnância que a aflige. Por fim Helena ( $\mathrm{Hel}$. 273-275) sente-se também ela escrava, só e indefesa perante a prepotência do faraó apaixonado.

O exílio servil em terra de bárbaros determina um conflito humano que as tragédias aventurosas de Eurípides resolvem pela fuga dolosa, a caminho do regresso à pátria e à civilização. Um conflito entre Grego e Bárbaro desencadeia-se no espaço estreito de uma contenda pessoal. Normalmente, ao herói em perigo, que é em Eurípides sobretudo uma mulher, vem juntar-se um comparsa, seu aliado na elaboração e execução de um plano de fuga. $\mathrm{Na}$ impossibilidade de um entendimento ou negociação com o Bárbaro, que estão excluídos entre os dois universos em conflito, a salvação tem de ser obtida pela coragem, mas sobretudo pela inteligência e pelo talento imaginativo que congeminam um estratagema enganoso. Embora este tipo de acção faça parte de um padrão ficcional, torna-se expressivo de um conceito de diferentes mentalidades e nomoi. A superioridade de espírito assiste invariavelmente ao Grego, cuja maquinação acaba em sucesso. Ao Bárbaro cabe o papel do ingénuo e do vencido. E acima de tudo o jogo de forças entre ambos torna-se significativo, dentro da perspectiva que é a nossa neste momento, quando o dolo assenta na exploração de uma diferença de nomoi.

O Ciclope põe em aç̧ão o velho Ulisses polymechanos por excelência, o paradigma dos heróis sujeitos a perigos constantes, que lhes desafiam uma capacidade inesgotável de recursos de salvação. Este talento para a improvisação de meios de sobrevivência e de fuga, a subtileza de espírito, o recurso ao argumento convincente, a utilização subtil da imaginação parecem 
constituir as marcas principais do espírito grego, quando confrontado com os acidentes de uma viagem. Depois de assistir à deglutição de dois companheiros pelas mandíbulas do monstro, Ulisses, consciente da impossibilidade material de reagir, põe em funcionamento um estratagema capaz de aniquilar a vantagem temível do adversário. Informado já de que o vinho não faz parte da dieta local, o herói de Ítaca vai usá-lo para adormentar o inimigo (cf. $O d$. 9. 343-362, onde o herói se serve do mesmo dolo, não porque o Polifemo não conheça o vinho, mas porque o que lhe é proposto é excelente em qualidade). Trata-se não só de recorrer às potencialidades anestésicas de uma boa bebedeira, mas também de explorar uma diferença de costumes alimentares, que porá quem a domina ao controle de uma situação arriscada. Ulisses não oculta a noção de que está a aproveitar dessa divergência, quando proclama (vv. 413-415): 'Ó filho do deus do mar, ó Ciclope, vê só o que a Grécia é capaz de extrair da vinha, esta bebida divina, alegria de Dioniso'. Produto e festa são novidade para o selvagem, que não é, no entanto, insensível ao prazer do seu aroma. Ulisses prodigaliza as taças, certo do efeito perturbador do produto que a civilização aprendeu a preparar e a consumir com abundância, como também do sucesso de um estratagema que assegura a supremacia do Grego sobre o selvagem, do progresso sobre a barbárie ${ }^{(20)}$. Por isso, a vitória não lhe escapa, premiando-lhe o talento natural.

Situação paralela é a que vivem na Táuride Orestes e Ifigénia, como no Egipto Menelau e Helena. Em ambos os pares, o herói masculino propõe uma solução armada, de inspiração épica, segundo a qual um ataque violento contra o povo local ou o assassínio do seu rei poderiam proporcionar uma hipótese desesperada de fuga. Mas no Egipto o regicídio é inviável graças à presença da profetisa Teónoe que não deixará de o denunciar à vítima, evitando a eficácia do golpe. Neste caso, a superioridade e clarividência de

(20) Também Heródoto narra, em 1. 207, 211, um episódio em que a mesma táctica de domínio do civilizado sobre o selvagem é ensaiada. Ciro da Pérsia ganha, sobre os Masságetas, um ascendente ludibriando-os com os atractivos do vinho e de um banquete abundante. Apenas a vantagem obtida por Ciro é provisória, porque os Masságetas são inteligentes, corajosos e têm capacidade de reacção. O resultado final, no episódio de Heródoto, traz vantagem ao povo primitivo que são os Masságetas e causa derrota e morte aos Persas, que encarnam o paradigma da civilização avançada. A relação civilizado / selvagem é, em Heródoto, reequacionada de forma a reabilitar o espírito do povo à primeira vista considerado inferior. Sobre a convenção deste tipo de episódios literários que assentam na rivalidade dos méritos do Grego e do Bárbaro nas Histórias, vide S. Flory, The archaic smile of Herodotus (Detroit, 1987). 
espírito assistem ao bárbaro e protegem-no contra a ameaça do guerreiro grego. Na Táuride, Ifigénia não consente golpe semelhante por respeito ao nomos da xenia. O princípio que o Bárbaro não conhece faz a distinção com a excelência, agora moral, do Heleno. Ainda que ameaçada de perigo extremo, a filha de Agamémnon faz questão de evitar o que seria uma infracção à sagrada regra do civismo (v. 1021): 'Criminosa é essa proposta que fazes de estrangeiros assassinarem o seu hospedeiro’. Por outro lado, a prudência e o recurso ao dolo, que salvam, são nos dois episódios fruto do talento feminino. É no âmbito das suas funções religiosas que Ifigénia encontra pretexto para se dirigir ao mar com os dois prisioneiros, juntamente com a imagem da deusa. Embora o culto decorra em terras da Táuride, com regras diferentes das que vigoram na Grécia, a ideia da poluição da deusa e da necessidade de purificação congregam a perspectiva grega e bárbara (v. 1189). A ambos parece legítimo que Ártemis manifeste repugnância ao contacto de mãos matricidas; e como a ironia domina na cena de dolo, Toas pode até denunciar tal crime como excessivo aos olhos de um selvagem sanguinário (v. 1174) ${ }^{(21)}$. A forma como Ifigénia foi capaz de se sair de dificuldade, averiguando as causas da animosidade divina e encontrando para ela uma solução - o que é ao mesmo tempo cumprir determinações divinas com vista à fuga para a Grécia - é reconhecida pelo Bárbaro - na pele da vítima do dolo - como 'talento próprio do engenho grego' (v. 1180). $\mathrm{E}$ aproveitando-lhe a sugestão, Ifigénia pede que as vítimas sejam postas a ferros, 'porque todos os Gregos são pérfidos' (v. 1205), ganhando com esta confissão por demais verdadeira a confiança do enganado. À montagem do engano não é estranha a ideia de que uma confluência de nomoi põe em sintonia os propósitos de Ifigénia e de Toas e lhes harmoniza vontades e decisões. Mas o sucesso da empresa ilumina sobretudo uma diferença de espírito, onde o Bárbaro se consagra como ingénuo, para além de brutal, uma e outra atitude denunciadora de falta de convívio humano, e por isso se coloca na eterna posição de inferior e vencido diante da habilidade experimentada de um grego.

(21) Naturalmente que ao espírito grego repugnavam também os crimes cometidos contra parentes, embora na expressão mítica eles sejam mais numerosos dentro das cortes gregas - são flagrantes os casos de Micenas e de Tebas - do que em horizontes bárbaros. Mesmo assim, a noção de que a violência no plano familiar é própria de comunidades bárbaras é explicitada, sem rodeios ou atenuantes, por Hermíone na sua fúria contra a concorrência involuntária de Andrómaca ao seu leito conjugal (Andr. 168-177). 
Helena, em contrapartida, também ela o génio de uma estratégia de fuga, segue na mesma senda de Ulisses: explora a diferença de nomoi para iludir a ingenuidade de Teoclímeno, a quem a estupidez bárbara e a cegueira da paixão ditam todas as cedências; sem deixar de se valer da situação extrema de Menelau como inspiradora do projecto. Anunciar a morte do marido, como promessa de quebra de compromissos e de cedência aos desejos do enamorado faraó, justifica que se peça autorização para um rito fúnebre. A anuência de Teoclímeno a este pedido é previsível e fácil; mas resta um pormenor bloqueador, obter um barco que, no decurso dos funerais, viabilize a fuga do Egipto para a Grécia. É na solução desta exigência que o talento de Helena se distingue (vv. 1065-1066): 'Podemos dizer que os costumes gregos proíbem o enterramento dos que morreram no mar'. A ideia parece promissora: afinal como pode haver lugar a dúvidas e a desmentidos? Teoclímeno anui a proporcionar os funerais; é-lhe dada até preferência na escolha das vítimas para o sacrifício aos mortos de acordo com os hábitos do seu país, para que a diferença nos pormenores dos rituais se lhe torne palpável. E se há diversos costumes quanto aos animais dedicados ao morto - um cavalo ou um touro segundo a prática bárbara, v. 1258 -, porque os não haverá também para a escolha do elemento natural que há-de acolher o cadáver, terra ou água? (vv. 1241-1247, 1267). O sucesso do logro advém da diferença de nomoi, que, no caso da aventura vivida no Egipto, não é sequer verdadeira. $\mathrm{O}$ que Helena defende como hábitos gregos é uma pura invenção para servir uma necessidade concreta do plano de fuga. Tanto mais sugestiva a ideia da consciência que se vai tornando clara de que as diferenças existem, são naturais e respeitáveis e podem contribuir para uma verdadeira cooperação entre os homens; mesmo quando não passam de simples recurso ao serviço do talento grego para o logro e para o aproveitamento da credulidade bárbara.

Para além do aproveitamento aventuroso e romanesco do motivo do bárbaro, construído sobre a dicotomia e os critérios tradicionais que dão a supremacia ao Grego sobre um adversário incivilizado e inferior e consagram como invariável a vitória do herói exilado ou viajante em território longínquo, o tema da guerra entre Helenos e outros povos conheceu, na produção de Eurípides, uma grande expansão e produziu um símbolo das consequências extremas da violência, num plano geral. Fazendo jus à tradição, a guerra de Tróia continuou a funcionar como eterno paradigma de um conflito arrasador, para onde remetia a experiência que o mundo contemporâneo 
de Eurípides, envolvido na Guerra do Peloponeso, diariamente conhecia; afinal todas as guerras são semelhantes, nas agruras e sofrimentos que comportam. Mas são-no também como espaço de instabilidade social, de questionamento dos princípios estabelecidos e de decadência civilizacional. Tróia e a campanha grega de que foi alvo representam a animosidade entre diferentes comunidades, entendida no plano colectivo. Embora asiática e estrangeira, a cidade de Príamo sempre gozou, dentro do critério grego, de um estatuto que tendeu a aproximá-la, em termos de estádio de progresso, da própria Hélade e a colocou na posição de um inimigo à altura. Este equilíbrio está claramente subjacente à Ilíada e manteve-se, de uma certa forma, na época clássica, sem ter deixado de sofrer alguma remodelação sob a influência da memória das Guerras Pérsicas. Ao reconhecer, sob a legenda 'Troianos', uma mescla de Frígios, Persas e Bárbaros, o séc. V introduzia um dado novo na imagem tradicional dos inimigos dos Aqueus. Apesar disso, o conceito de barbárie nunca lhes foi atribuído como estigma que os depreciasse ao nível do selvagem ou do primitivo. No entanto, nas duas tragédias euripidianas que mais directamente focam o drama da antiga cidadela frígia, Troianas e Hécuba, a velha polémica Grego/Bárbaro não está ausente, mas permite uma reavaliação perspectivada noutros termos: a noção de um Grego selvagem e de um Bárbaro superior vem subverter por completo as tradicionais regras do jogo, à melhor maneira do poeta revolucionário e do pensamento sofístico de que se sentiu sempre muito próximo $^{(22)}$.

Tróia podia orgulhar-se da majestade robusta das suas muralhas, obra dos deuses devotados à cidade ( $T r .4-6,814)^{(23)}$, que protegiam o esplendor das suas riquezas. $\mathrm{O}$ ouro brilhava como insígnia constante dos seus tempos de glória (Hec. 492, 925-926, Tr. 994-995, 1074-1075), as festas fizeram-lhe vibrar as ruas até ao último dia da sua existência (Hec. 917-918, Tr. 1071-1073). A glorificação dos deuses, por outro lado, constituía actividade

${ }^{(22)}$ Antifonte (fr. 44 A7 B2 Diels) é um outro testemunho da tendência sofística para negar as tradicionais diferenças existentes entre Gregos e Bárbaros. Outros testemunhos gregos podem ser invocados que apontam para a mesma posição, como se pode constatar em N. T. Croally, Euripidean polemic. The Trojan women and the function of tragedy (Cambridge, 1994), 112. Na sua amplitude toda a questão foi objecto do vol. VIII dos Entretiens Hardt, Grecs et Barbares (Genève, 1962).

(23) Sobre a lenda da construção de Tróia, cf., e. g., Il. 7. 452, 21.442 sqq.; Pi. O. 8. 31-32; E. Andr. 1009-1017. 
permanente da cidade piedosa de Príamo. Logo à cidadela não faltava a arquitectura de uma pólis nem o convívio de uma verdadeira sociedade humana; se algum pormenor bárbaro se patenteava deste quadro de prosperidade oriental, esse seria sem dúvida o fausto e a riqueza incontável que guardava. A própria Grécia, na sobriedade que desde sempre a caracterizou, não podia ombrear em riqueza com a dourada Tróia, nem com o esplendor oriental dos seus trajos (Tr. 991-996, IA 73-74). Foi esse fascínio que arrebatou Helena da corte modesta de Esparta e a converteu na causa de um longo conflito. Mesmo quando as portas da fuga lhe eram oferecidas como forma de pôr fim a uma guerra que se eternizava, a bela rainha recusou; são claros e acusadores os termos com que Hécuba lhe denuncia a rendição ao luxo e ao requinte troianos (Tr. 1020-1021): 'A esse orgulho desenfreado que tens fazia falta o palácio de Alexandre, desejavas receber a adoração de bárbaros'. Assim Tróia, em fausto, suplantava a Grécia, mas mesmo entre o fulgor do oriente brilhava como jóia rara (Tr. 1277-1278): 'Tróia, que respiravas de orgulho no meio de bárbaros'. Bárbara apenas porque não grega, a velha cidadela impunha-se pelo poder e magnificência. Mas nem só o bem-estar exprimia um estádio de desenvolvimento invejável; a cidade da Frígia partilhava, com as comunidades evoluídas, de valores civilizacionais elevados, como o da xenia.

Mas por ser humana, e por isso sujeita à vontade dos deuses e aos imprevistos do destino ${ }^{(24)}$, Tróia ruiu qual paradigma trágico, numa queda fatal da prosperidade maior na extinção mais completa. Importa, no entanto, recordar que a arma decisiva que a tornou ao fim de tantos anos vulnerável não foi a força, mas o engenho humano, o dolo arquitectado por um Grego, o Ulisses polymechanos. Com o estratagema do cavalo de pau ${ }^{(25)}$, que atraiu sem reticências os encantos de um povo que nele viu um prodígio de beleza e uma dádiva digna de deuses, Ulisses fez abrir as portas renitentes de Tróia. A par da finura de um Grego, alguma ingenuidade bárbara vinha favorecer as vontades divinas que ameaçavam o reino de Príamo.

${ }^{(24)}$ Helena (Tr. 924-934) recorda, como causa primeira do desfecho desta guerra, o julgamento das três deusas nas montanhas do Ida, que Páris, por seu mal, arbitrou. Aí, numa tentativa de subornar o juiz, Atena (estranha versão! Cf. vv. 971, 974) prometeu-lhe o domínio da Hélade, enquanto Cípris lhe acenava com a dádiva da bela Helena. Se a opção de Páris causou aos Troianos a ruína completa e aos Aqueus um longo sofrimento, poupou pelo menos a Grécia à eterna ameaça bárbara.

(25) Sobre o estratagema do cavalo de pau, cf. Od. 4.270 sqq., 8. 502 sqq.; E. Tr. 9-14, 511-541. 
A prosperidade da cidade frígia só interessa a Eurípides como um pano de fundo cuja lembrança torna mais dolorosa a decadência actual, que circunda as tragédias que o poeta dedicou ao pós-guerra, Troianas e Hécuba. Mortos os seus defensores, apenas as mulheres, cativas dos vencedores, testemunham ainda o incêndio que fez de Tróia um simples recorte a negro da majestade passada. Mas neste campo de ruínas, Gregos e Asiáticos disputam ainda os últimos destroços de um longo conflito. Nas decisões dolorosas que acompanham os últimos momentos da cidadela, se os Frígios, vencidos e humilhados, são bárbaros apenas porque não Gregos, os Helenos mostram-se igualmente bárbaros, mas porque assassinos e selvagens no comportamento para com os derrotados. O sacrifício de Políxena ao fantasma de Aquiles merece a Hécuba a justa acusação de 'impiedoso' (v. 628). A condenação de Astíanax, criança ainda, à morte como símbolo da extinção definitiva a que se deseja remeter a raça troiana merece a Andrómaca, a imagem da mãe indefesa e impotente, esta denúncia sofrida (Tr. 764-765): 'Ó Gregos, inventores de suplícios bárbaros, que interesse é o vosso na morte desta criança inocente?’. Tudo parece subvertido no plano geral da peça: os Gregos actuam de forma mais bárbara do que os próprios Bárbaros; estes assumem critérios gregos na avaliação dos acontecimentos e na denúncia da violência reinante; e a Helena, a grega em território bárbaro seduzida pelo luxo oriental, é reservada uma posição intermédia e por isso indefinida e ambígua.

As grandes crises políticas e militares que assolaram a Grécia ao longo do séc. V a. C. impuseram uma reavaliação do relacionamento entre as cidades que compunham a comunidade grega bem como entre estas e os outros povos, e em simultâneo uma revisão do sentido de bárbaro. Primeiro foi necessário opor resistência a um oriente que se revelava como nunca um universo de povos estranhos, de costumes desconhecidos, de onde emergia uma ameaça violenta. Mas, ao mesmo tempo que media forças com o enorme potencial persa, a Grécia adquiria a noção das nuances que tornavam o 'Bárbaro' uma mescla diferenciada de diversas comunidades. Aí se percebiam diferentes estádios civilizacionais que, avaliados em confronto com a cultura grega, se podiam hierarquizar como mais ou menos bárbaros. Mais do que nunca se impôs a ideia da diferença ou do perigo que o 'outro' representava, se contactado no seu terreno ou em campanha invasora contra a Grécia, como se justificou a conviç̧ão da superioridade helénica. Mas uma nova experiência se sucedeu à vitória inesquecível do 
Grego sobre o inimigo asiático. O conflito que desta vez opôs Gregos contra Gregos, numa disputa pela supremacia do poder, veio tornar patente que o perigo e a violência, marcados por uma ferocidade bárbara, podiam eclodir dentro do próprio mundo civilizado, onde o grau de agressividade podia atingir extremos impensáveis de selvajaria. Ficou patente, aos olhos de todos, que os que se julgavam superiores podiam, na crise, comportar-se como verdadeiros bárbaros e aceder a práticas que trazem o cidadão civilizado de regresso a uma bestialidade primitiva. 'Bárbaro' apelidou então um comportamento selvático e animal a que todo o ser humano, em tempo de guerra, está sujeito.

Toda esta problemática fundamenta a peça que recebeu o nome da viúva de Príamo, Hécuba. Entre as diversas leituras a que uma tragédia de difícil interpretação foi sujeita destaca-se aquela que D. Kovacs ${ }^{(26)}$ define com estas palavras eloquentes: 'Um dos mais importantes contrastes existentes na peça é estabelecido entre Gregos e Bárbaros, um contraste que coincide com o que opõe figuras dinásticas, como a rainha e a princesa de Tróia, e membros de uma sociedade democrática, como Ulisses ou Agamémnon. Este contraste desenvolve-se não só em discursos explícitos, como aquele que Ulisses dirige a Hécuba (vv. 326-331), mas também no modo como Gregos, Troianos e Trácios são retratados'.

Desde logo o próprio contexto é expressivo. Por cenário da acção o poeta preferiu a Trácia, onde reina o bárbaro Polimestor ${ }^{(27)}$, um terreno selvagem com que Gregos e Troianos são obrigados a conviver graças à posição geográfica que ocupa entre os dois territórios. Pormenores vários apontam para a riqueza natural da região (Hec. 8-9) e para as potencialidades militares que possui (vv. 9, 1088-1090). Mas uma verdadeira cidade construída parece não existir, para além do que vagamente se refere como 'a morada' de Polimestor (vv. 995, 1134, 1212, 1245). Como cenário dramático, o Quersoneso da Trácia é sobretudo uma terra remota, de tendências primitivas e ferozes, de comportamentos amorais, onde todos os valores civilizacionais parecem estar suspensos. Aí estacionam os vencedores helenos, de regresso a casa após dez anos de ausência, de conflito e de baixas, de posse das cativas troianas, viúvas, mães enlutadas e cidadãs de uma sociedade

\footnotetext{
(26) The heroic muse (Baltimore, 1987), 81.

${ }^{(27)}$ Sobre a figura de Polimestor como possível criação de Eurípides, vide Ra'anana Meridor, 'The function of Polymestor's crime in the Hecuba of Euripides', Eranos 81 (1983), 13-20.
} 
que acaba de se apagar do mapa das comunidades humanas. $\mathrm{O}$ contexto é, portanto, de sombras profundas, em que dois golpes derradeiros se preparam consumando o desespero de uma mulher e de um grupo que pareciam ter já atingido o limite da extinção; com a morte anunciada dos dois filhos de Hécuba que ainda restam - Políxena e Polidoro - os fumos da ruína fecham-se sobre Tróia e sobre a respectiva casa real com um adensar de negrume que não parecia mais possível.

Cabe ao fantasma de Polidoro antecipar, desde a abertura do prólogo, as condições que vão envolver este duplo golpe. Para além da sua própria morte já consumada ainda que não conhecida, a condenação de Políxena é também opção assente entre o exército aqueu. A vontade de Aquiles, manifestada do além túmulo, exige a imolação da vida da jovem troiana como troféu de eleição devido ao herói morto (Hec. 37-41). Estranho é o pedido do mais prestigiado dos combatentes gregos em Tróia, que soa como prática injusta e selvática. E, no entanto, o fantasma de Polidoro assegura a anuência dos companheiros do herói a tal exigência como algo estabelecido e incontestado (vv. 42-44). Pode parecer, à primeira vista, que só uma profunda crise explique tal acto de violência. Mas os acontecimentos encarregar-se-ão de mostrar que a decisão não passa exclusivamente por um acto de exaltação em clima de guerra, mas é fruto de uma opção consciente e medida, onde princípios de humanidade soçobram perante meros interesses de dimensão mesquinha. As mulheres do coro relatam com mais pormenor como, em assembleia, numa expressão de vontade colectiva, a decisão foi tomada. Da controvérsia que o coro diz ter-se instalado (vv. 116-119) entre os que aceitavam ou não a vontade do ausente, o espectador esperaria ouvir argumentos que discutissem justificações de um sacrifício bárbaro, que naturalmente repugna a espíritos civilizados. Apenas para ficar a saber que as razões determinantes tinham o sabor do pessoal e do secundário. Se Agamémnon votava contra, era tão só para não atingir a ligação amorosa que mantinha com Cassandra, a irmã da vítima (vv. 120-122); por seu lado os dois filhos de Teseu, heróis da radiosa Atenas, votavam a favor do sacrifício, para homenagearem o seu correlegionário, numa atitude de fidelidade ao ascendente grego que comporta neste caso o desprezo total pelo valor supremo da vida humana; sem esquecer, naturalmente, a antipatia pelos intentos perceptíveis do comandante, Agamémnon (vv. 123-129). Ulisses, que arbitrou o diferendo, não deixou de explicitar o seu ponto de vista: que nunca uma vítima servil poderia, por princípios de humanismo, 
interferir com a vénia devida a um herói da comunidade (vv. 130-140). Ao contrário dos dilemas profundos a que assistimos no Agamémnon de Ésquilo ou na Ifgénia em Áulide de Eurípides a propósito do sacrifício iminente de Ifigénia, desta vez não parece haver lugar a dúvidas sobre a terrível decisão. É patente, nesta sociedade democrática onde as decisões são tomadas pelo voto das massas, que, acima da vontade dos chefes, pondera a posição colectiva, susceptível de resto de ser manobrada pela subtileza de um novo espírito político. Onde falta a autoridade dos aristocratas, sobeja a habilidade dos demagogos a determinar o sentido das decisões colectivas. Neste contexto, argumentos defensores de interesses anónimos e comunitários têm o condão de se sobrepor a todos os princípios.

A defesa da vítima, que não tem procurador na assembleia dos Aqueus, vai caber a Hécuba, a mãe e rainha de Tróia, a representante do 'outro', o estrangeiro vencido, diante de um Ulisses que aparece como mensageiro da decisão grega. Todos os que esperavam que um tal debate sobre a legitimidade de um sacrifício humano tivesse de situar-se no plano dos supremos princípios universais vêem agora chegado o momento que aguardavam. Não sem registarem que é Hécuba, a estrangeira, a colocá-los e a defendê-los perante um Ulisses que mal inventa sofísticos argumentos para o seu incumprimento. Contra o acto bárbaro que se anuncia é invocado, em primeiro lugar, o sacro princípio da hospitalidade, que se traduz na protecção devida aos suplicantes com a inevitável contrapartida da retribuição. Hécuba cumpriu-o com escrúpulo em tempo de guerra, quando em Tróia o mesmo Ulisses corria perigo de vida. Infiltrado na cidade frígia como espia, o rei de Ítaca, sob disfarce de mendigo, foi denunciado a Hécuba por Helena, que o reconheceu. Apanhado em terreno inimigo, Ulisses suplicou da generosidade da soberana a salvação, que não deixou de lhe ser concedida ${ }^{(28)}$. Agora que a sorte inverteu posições, à velha rainha assiste o direito de pedir para a filha em perigo a salvação, como justa contrapartida (vv. 239-253). Outra regra se soma a xenia como princípio subjacente a uma sociedade humanista, a philia ou solidariedade devida aos amigos, também ela um valor recíproco (vv. 255-257, 286). Subjaz todavia ao contexto da peça como ao da realidade - é preciso também reconhecê-lo - um tremendo conflito de lealdades e de retribuições a que todos os homens estão sujeitos. Assim, se Ulisses

${ }^{(28)}$ Cf. Od. 4. 244-258, onde episódio semelhante é narrado, embora sem a participação de Hécuba. 
deve a Hécuba retribuição da generosidade com que o libertou outrora, deve também a Aquiles, como soldado grego, a dádiva da vida que o herói da Ftia não hesitou em comprometer em nome da vitória dos Aqueus. $\mathrm{E}$ os interesses de Hécuba e de Aquiles são, na conjuntura presente, opostos. Por outro lado, como sobrepor à elevação dos princípios a exigência de um sacrifício humano, quando a imolação de animais poderia satisfazê-la plenamente? (vv. 260-261) ${ }^{(29)}$ A pergunta formulada por Hécuba traz ao debate a controvérsia do que é um ritual civilizado ou bárbaro. Porque não há sequer uma fatalidade a justificar a imolação de uma donzela, este acto patenteia-se como uma simples prática selvagem que repugna ao bom senso de qualquer mentalidade evoluída. Há, por fim, além de todos os valores universais e humanos, a própria lei grega que prescreve punição equivalente para os autores de assassínio seja a vítima livre ou escrava (vv. 291-292). Mas o apelo efusivo de Hécuba à moralidade, religião, deveres pessoais e legalidade parece perder todo o sentido diante do racionalismo, frio e pragmático, de Ulisses, que só interesses concretos e imediatos determinam. Depois de traduzir uma enorme perplexidade sobre a aplicação de regras e princípios num mundo conturbado, Eurípides reserva-nos ainda uma ironia final. Com arrogância indisfarçável, Ulisses, numa tirada que pretende pôr um remate à discussão, avança com a questão Grego / Bárbaro (vv. 326-331): 'Nós, se não soubermos honrar o herói, seremos apodados de insensatos. Vocês, os bárbaros, não tratem os amigos como amigos e deixem de prestar aos mortos a vossa homenagem. Nesse caso a Hélade há-de prosperar, e vocês de recolher o fruto que merecem pelas vossas decisões'. Esta radicalização injustificada, a denunciar a repetição acrítica de uma opinião gasta, não tem outro objectivo que não seja o de encerrar uma questão dolorosa com o silêncio daquele que, nas circunstâncias, é o mais fraco. Porque prestar homenagem a um philos morto não é um valor absoluto, mas uma mera possibilidade cujo cumprimento pressupõe, no caso concreto, o desrespeito por outros princípios também fundamentais. Será de novo uma voz não grega, agora a de Políxena, a denunciar a falsidade do sofisma e a dispensar Ulisses do respeito devido aos suplicantes (vv. 342-347). Tão só porque a jovem está disposta a sofrer voluntariamente a morte, em nome de uma dignidade aristocrática que a impede de uma súplica humilhante e da resignação a uma existência de escrava.

${ }^{(29)}$ É muito claro, na lógica da peça, que o sacrifício de Políxena não é obrigatório, mas uma opção do exército grego face a um conjunto de critérios, de natureza política e pessoal. 
O quadro que mais tarde Taltíbio virá relatar do sacrifício de Políxena repõe, nos seus devidos lugares, a escala de valores que parece tão deturpada em todo o processo que conduz a este desfecho supremo. A emoção que se apodera do mensageiro é já sinal de um sentimento de admiração, espontâneo num homem simples, pelo que é de facto superior e belo (vv. 518-520). Por entre a solenidade ritual com que os ofertantes conduziram o sacrifício, coube à vítima, pela sua dignidade, o papel central. Sem hesitações ou sustos, livre enfim na morte do toque humilhante de mãos inimigas, Políxena elevou-se, sozinha, perante o seu destino, no controle de todas as vontades que a cercavam. O povo aplaudiu, Agamémnon exprimiu a rendição geral à vontade da vítima (vv. 553-554). Com a elevação de uma estátua de linhas gregas, a jovem bárbara ofereceu-se ao golpe, para colher de seguida, de todas as mãos, as coroas devidas à sua vitória em nome de uma verdadeira arete. Sem subterfúgios retóricos nem apelos humilhantes, Políxena mostrou-se como verdadeira aristocrata, apesar de não grega. Contradizendo as palavras de Ulisses sobre a vénia devida aos heróis da comunidade, a mesma comunidade dobrava-se agora perante os méritos de outros heróis, que respondiam à barbárie de uma exigência discutível com o sacrifício incondicional da vida em nome de um valor supremo: a liberdade. Por isso lhe foi devida, como a Aquiles, a homenagem póstuma de uma sociedade que dela recebeu a dádiva útil da vida.

Se os valores da xenia e da philia estavam já em causa no plano das convenções de guerra e dos comportamentos civilizados entre inimigos - os que ligavam Hécuba como rainha de Tróia a um Ulisses representante dos interesses do invasor -, os mesmos princípios ganham nova expressão no conflito que irá colocar-se entre Hécuba e o trácio Polimestor. Ainda em tempo de paz, entre o senhor da Trácia e o de Tróia existia um pacto de mútua colaboração (vv. 7, 19, 26, 82). Mais do que num simples protocolo, esta convivência assentava na amizade pessoal e na confiança mútua. Assim se explicou que, quando o perigo de uma invasão ameaçou Tróia, Príamo tenha, em segredo, confiado o seu descendente mais jovem à guarda do seu hóspede (vv. 4-15), juntamente com um pequeno tesouro que se destinava a garantir-lhe a sobrevivência. Polimestor respeitou o acordo, enquanto Tróia resistiu; mas mal a possibilidade de um ajuste de contas desapareceu com a própria ruína da cidade e com a morte dos que a defendiam, a atracção do ouro pesou mais forte e o Trácio não hesitou em eliminar o seu protegido para se apoderar do ouro (vv. 21-27, 1206-1207, 1243-1245). Mais ainda, com um total desrespeito 
pelos mortos, nem mesmo cuidou de dar ao cadáver da sua vítima sepultura (vv. 26-30). São estas as linhas gerais de um outro conflito humano, que desta vez coloca frente a frente uma troiana, de novo na defesa dos valores humanos, e um trácio que representa a falsidade e a traição, num desrespeito total, que é a marca denunciadora da barbárie, pelo poder da lei e dos valores.

O achado surpreendente do cadáver de Polidoro a boiar nas águas do mar, por uma serva que recolhia água para os funerais de Políxena, não deixa em Hécuba a mais pequena hesitação: a culpa impende sobre o hóspede de seu marido, que o recebeu das mãos do pai à sua guarda e se deixou seduzir pelo atractivo do ouro (vv. 710-712). Do sentido moral e cultural desse acto, a rainha de Tróia não deixa dúvidas (vv. 714-715): 'Crime indizível e sem nome, a passar as raias do espanto, ímpio, intolerável! Onde está a justiça devida aos hóspedes?' E, ao alistar diante de Agamémnon, as culpas do Trácio, Hécuba pode precisar: a total deslealdade de um hospedeiro, que revela impiedade para com os deuses e desumanidade para com os homens (vv. 789-792); a traição para com hóspedes generosos e amigos, que o acolheram com afeição à sua mesa como o proferido dos comensais e lhe dispensaram todas as atenções (vv. 793-796); por fim, o desrespeito para com os mortos, que permite que se deixe insepulto um cadáver (vv. 796-797). Todos estes actos são selvagens e contrários a uma ordem moral que tem de encontrar nos homens justos e civilizados os seus defensores. Porque é essa lei o árbitro universal, que permite distinguir o verdadeiro progresso humano da barbárie, cuja eficiência depende dos homens livres com legítimas competências na sua salvaguarda (vv. 799-806). De novo os Gregos são postos diante de um crime, como árbitros e defensores de um civismo que se faz do respeito pela lei. E mais uma vez hesitam e recuam, porque outros valores, pessoais e políticos, os levam a distorcer o mérito puro dos princípios. Agamémnon não quer desagradar aos homens sob seu comando punindo um aliado, Polimestor, em favor dos inimigos vencidos, de resto aniquilados e inúteis (vv. 852-860). Menos ainda o chefe supremo do exército quer expor-se como alguém que cede aos instintos baixos da paixão por Cassandra, irmã também desta outra vítima. É agora o Atrida quem se vê apanhado na rede de difícil gestão da lealdade devida à justiça e aos amigos: repartido entre os interesses de Polimestor como aliado dos Gregos e os de Hécuba, a quem de certa forma o ligam laços de família. Mas, por seu mal, os objectivos do Trácio e da Troiana que apelam à sua autoridade são manifestamente opostos. 
À peça onde a barbárie generalizada reconquista um vasto espaço, como se o mundo em conflito, que é o dramático como o vivido por Eurípides, promovesse o recuo às mais agressivas e descontroladas reacções humanas, está reservado um final de violência entre todas as forças em litígio. Hécuba tem agora com Polimestor um novo debate sobre o tema xenia; com Ulisses a discussão prosseguia, a partir da declaração frontal do herói da decisão do sacrifício de Políxena, através de um longo e hábil esgrimir de argumentos, com vista à suspensão ou cumprimento de uma atrocidade. Agora um diálogo esticomítico permite a Polimestor responder ao questionário frontal de Hécuba com mentiras prontas, fingindo uma normalidade que todos, heroína e público, sabemos ser falsa. Não há, a nível dos princípios, muita diferença entre os dois interlocutores de Hécuba, o grego e o bárbaro: ambos desrespeitam as regras da xenia e da philia. Mas fazem-no dentro de uma mentalidade claramente diversa. Ulisses é falso e amoral, mas habilidoso no uso do discurso e das subtilezas do argumento; logo comporta-se com a crueldade sofisticada de um civismo barbarizado. Só nos processos Polimestor difere dele, porque o seu móbil é tão só o atractivo do dinheiro e a sua argumentação não vai além da mentira primária e descarada. Falta-lhe subtileza, e por isso encarna o bárbaro vulgar, de uma agressividade primitiva e rasteira.

É chegada a hora do ludíbrio do bárbaro, de que mais uma vez uma mulher é a autora; mesmo se não grega, Hécuba detém um talento equivalente para o consumar. Não a move um objectivo plausível de fuga para a liberdade, como os que impulsionavam Ifigénia ou Helena. Hécuba satisfaz-se com a vingança, dobrada à violência desumana de toda a situação. O logro desta vez é muito simples, à medida da ambição primária do Trácio; o objectivo desejado é a condenação à morte dos filhos de Polimestor - como contrapartida das perdas sofridas pela própria vingadora - e a aniquilação da sua dignidade de homem. Logo a morte ou a violência física que Ifigénia rejeitava pelo dever para com estrangeiros e Helena sentia impossível face à oposição esclarecida de Teónoe ${ }^{(30)}$ é aqui o sinal de sucesso de um dolo que Hécuba prepara sozinha e executa com a conivência das suas companheiras de escravidão. Basta atrair as vítimas ao recôndito das tendas das cativas; e, para tal, Hécuba não tem mais do que, em imaginação, recheá-las de ouro, resquício ainda dos velhos tesouros da cidade agora abatida. Está conseguida a anuência da vítima aos seus desígnios.

\footnotetext{
(30) Vide supra pp. 203-204.
} 
Que desfecho está reservado a uma crise onde os princípios mais sagrados estão em causa, porque desconhecidos de uns, porque abolidos por outros quando colocados no extremo do desespero e do abandono, ou ainda porque ignorados em função de interesses restritos e menores? $\mathrm{O}$ recontro final só pode ser uma explosão de barbaridade exemplar e bestial. Por vingança, o único objectivo que a orienta neste momento, Hécuba matou os filhos de Polimestor para pagar, com a eliminação da descendência do inimigo, a morte da sua própria descendência, numa aplicação radical da pena de talião (v. 1086). Ao Trácio reservou a cegueira, um mal que o deixa vivo para prolongar, na escuridão das trevas, uma existência indesejável. Um confronto final entre carrasco e vítima, sob o olhar avaliador de Agamémnon, permite criar ao vivo, nos gestos e nos gritos em cena, o quadro limite da selvajaria reinante. Hécuba prevê a vinda iminente de Polimestor enfurecido, entregue a uma raiva animalesca, como um verdadeiro Trácio (vv. 1054-1055). E ele aí está diante dos nossos olhos 'a quatro patas como uma fera das montanhas' (v. 1058), numa atitude denunciadora da sua verdadeira natureza, a gritar palavras de perseguição e de vingança. $\mathrm{O}$ devorar das carnes do inimigo, o castigo limite da antropofagia, preenche-lhe o espírito como a saída adequada para uma punição conveniente (vv. 1071-1075). Brada por ajuda, chamando em seu socorro os homens de armas, esses Trácios belicosos de que Polimestor dá um retrato esperançado como se na sua força militar residisse ainda alguma salvação (vv. 1088-1090): 'Socorro, Trácios, lanceiros, homens armados, bons cavaleiros, raça inspirada pelo sopro de Ares'. Na hora da derrota, sobrevémlhe ainda a imagem do povo belicoso que comanda, em toda a sua potência militar e máscula, quando em sua volta 'um exército' de simples mulheres, cativas e desarmadas, representa o inimigo a abater. Só uma raiva furiosa pôde operar o milagre, extraindo da fraqueza feminina uma ferocidade destruidora (vv. 1095-1097); assim o reconhece também Agamémnon quando chega atraído pelos gritos no acampamento, numa avaliação objectiva das forças activas no quadro com que se depara (vv. 1116-1123).

Com a chegada do Atrida, a barbárie envolvente conhece uma trégua em nome da necessidade de um julgamento formal e aparentemente equitativo das razões em litígio. Uma simulação de justiça, sob a forma de um julgamento em que as duas partes terão voz, arreda por um momento a ferocidade primária dos dois contendores. A oposição entre um comportamento bárbaro, expresso por uma violência incontida, e o 
apropósito civilizado de um julgamento fica patente da recomendação com que o Atrida cala os brados do Trácio (vv. 1129-1131): 'Põe de lado essa fúria de bárbaro e fala; para que eu depois de vos ouvir, a ti e a ela, um de cada vez, possa julgar com justiça que motivos justificaram o teu sofrimento'. No agôn que então decorre, onde o Bárbaro é chamado a participar num debate 'à grega', desconhecido dos seus hábitos de pura violência física, o Polimestor euripidiano é capaz de um esforço de habilidosa argumentação. O bom senso manda-o confessar agora o assassínio do seu hóspede, que antes negara diante de Hécuba, mas que passou a ser público e indesmentível (vv. 1132-1136). Xenos, no entanto, é palavra que não entra na confissão, ou porque o bárbaro desconhece o princípio, ou porque lhe não convenha explicitá-lo como agravante que é do seu procedimento. A mentira transita agora do acto consumado para os motivos que o justificam e esses são os interesses de Agamémnon - ver definitivamente aniquilada a cidade inimiga e o seu povo - e os dos próprios Trácios - o de se protegerem de futuras incursões armadas através do seu território. Por fim, a descrição pormenorizada do dolo de Hécuba, a ocultar uma arremetida traiçoeira contra vítimas indefesas, culmina uma argumentação que permita pedir como legítimo o apoio de um juiz de quem o bárbaro se diz amigo e de quem espera a punição de uma violência ... bárbara. Ao público é facultada a visão de um engano que ouvira anunciar e de que presenciara as tremendas consequências, sem ter podido segui-lo nos pormenores ocultos no segredo das tendas. Mas importa, para os nossos objectivos, dedicar-lhe alguma atenção, porque as diferenças culturais mais uma vez tiveram no logro o seu papel. Não foi difícil atrair Polimestor ao mundo das cativas, sozinho, porque o pretexto de recolher o ouro que aí se encontrava num segredo total foi isco bem sucedido junto da atracção primária do bárbaro pelo dinheiro. Lá dentro, a sedução continuou para permitir a aproximação insuspeita de um exército de cativas. Fingiram as mulheres uma curiosidade bem feminina pela novidade dos trajos trácios, obra de teares edónios (vv. 1151-1154); e logo passaram ao interesse pelas lanças trácias que tomaram nas mãos, despojando delas o seu possuidor (vv. 1155-1156). Como sempre a exploração das diferenças culturais é usada, agora de uma forma elementar - a curiosidade por simples objectos de uso comum -, para neutralizar o inimigo, com uma eficácia total.

Como é regra de um agôn baseado numa argumentação forense, o discurso de defesa que Hécuba a seguir pronuncia organiza-se como a 
resposta directa às considerações da parte contrária. A rainha de Tróia nega, antes de mais, qualquer philia por parte do Trácio para com Agamémnon. E o seu principal argumento tem o tom de uma verdade universal (vv. 1199-1201): 'Para começar, miserável, nunca os Bárbaros hão-de ser amigos dos Gregos, nem tal seria possível'. Logo o assassínio de Polidoro - 'o hóspede', nas palavras de Hécuba, para que o crime ganhe os seus verdadeiros contornos (v. 1216) - não teve outro móbil que não fosse uma ambição primária diante do fascínio do ouro. Philia, o sagrado princípio da cooperação humana, falhou também por completo na actuação do bárbaro (vv. 1218-1232): para com o hóspede, cuja vida poupou nos tempos felizes em que Tróia resistia ainda, mas que executou sem piedade quando a desgraça deixou os velhos aliados em ruínas; para com os Aqueus, a quem não concedeu, nas horas difíceis do pós-guerra, o apoio que o ouro podia representar para amigos em dificuldades. Sempre o ouro teve no espírito de Polimestor um ascendente sobre os valores civilizados da xenia e da philia. Por fim, Hécuba pretende suster qualquer vaga piedade que o sofrimento aplicado ao bárbaro pudesse despertar no juiz. Ele é tão só o castigo devido àquele que desconhece ou infringe as regras que têm de reger o convívio humano (vv. 1234-1235): 'É um homem sem piedade, sem respeito pelo dever, um hóspede ímpio e injusto esse que tu vais favorecer'. Este é o quadro que define o espírito bárbaro, não só porque não grego, mas porque infractor de todos os princípios em que assenta uma sociedade civilizada. Embora, naturalmente, o critério por que se avaliam os factores do progresso humano seja obra do mesmo grego.

Que os argumentos de Hécuba tinham o peso da legitimidade mostra-o a adesão imediata que ganham da parte de Agamémnon (vv. 1243-1251); esta concordância não deixa dúvidas sobre a proximidade cultural que os Gregos reconheciam no lado troiano. De facto, confirma o Atrida, a ambição do ouro pesou mais no comportamento do Trácio do que xenia ou philia. Há apenas uma divergência na sentença dada por Hécuba quanto à natureza ilegítima e ímpia da actuação de Polimestor, que ela considera no plano universal - agir como um ser humano ou com uma bestialidade bárbara são os termos da verdadeira dicotomia - e a forma como Agamémnon se refere à divergência nos comportamentos humanos; para o Atrida, o contraste permanece o que opõe Gregos a Bárbaros (vv. 1247-1248): 'Para vós, matar um hóspede pode ser coisa sem importância; mas para nós, que somos Gregos, é crime'. Um orgulho de raça muito convencional dita as 
palavras de Agamémnon, como se a fronteira da civilização continuasse a estabelecer-se pela linha geográfica que separa a Grécia do 'outro' que a rodeia. Toda a acção da peça é o desmentido desta afirmação do Atrida. A condenação e o sacrifício de Políxena revelara-se um acto bárbaro que os Gregos pretenderam validar com argumentos cívicos, mas pouco convincentes. $\mathrm{E}$ as previsões de Polimestor vão anunciar novos barbarismos na Grécia: o próprio Agamémnon, juntamente com Cassandra, o marido e a estrangeira, irão perecer às mãos assassinas de Clitemnestra (vv. 1275-1281). Com este quadro arrepiante, Polimestor destrói a imagem da legalidade e cooperação que o juiz do agôn acabara de montar do mundo grego e que a própria realidade desmente. Hécuba irá, por seu lado, sofrer uma metamorfose em cadela, num regresso manifesto a uma animalidade em que os extremos de uma vida desumanizada a projectaram. Neste negrume cerrado se consuma uma peça que deixa patente como um barbarismo puro, ao lado de uma civilidade excessivamente sofisticada e tendencialmente individualista, concorrem para desfechos que se não distinguem nas suas consequências limite: o regresso à violência primitiva e a uma bestialidade inata à natureza, não socializada, do ser humano. Esta é também uma peça exemplar para a subversão da habitual dicotomia Grego / Bárbaro, onde não é dado adquirido que aos Gregos assista uma superioridade incontestada e aos Bárbaros uma obrigatória selvajaria. Ainda que essa seja a leitura convencional da época, Eurípides não hesita em pôr em causa ou mesmo em subverter essa opinião. São, sobre o sentido desta leitura, expressivas as considerações com que E. Hall ${ }^{(31)}$ termina o seu estudo: 'Os Gregos barbarizados e os Bárbaros nobres de Eurípides têm por pressuposto o universo etnocêntrico definido pela tragédia (...). Corporizam uma inversão irónica e sofística da tese aceite de que os Gregos são superiores ao resto do mundo, um cânon tantas vezes sublinhado pelos poetas trágicos nas suas celebrações dramáticas de uma identidade colectiva grega, dentro do império ateniense'.

Para além desta policromia de situações, em que o recontro entre Gregos e Bárbaros reveste diversas cambiantes sempre em terreno estranho à Grécia, vamos considerar a outra perspectiva que resulta da presença do estrangeiro na sociedade grega. Neste caso, o exilado é o não grego e importa ver como se reflecte no seu quotidiano a integração, mais ou menos difícil, no mundo civilizado da Hélade.

(31) Op. cit., 222-223. 
Medeia é o exemplo de uma peça onde o tema do exílio constitui um elemento de algum relevo na coordenação das etapas da história. Afastada da terra natal, a heroína da Cólquida, com Jasão e os filhos, encontraram refúgio em Corinto, onde não deixam mesmo assim de se ver relegados a uma situação de estranhos; ela porque estrangeira, ele porque refugiado depois da partida da Tessália ${ }^{(32)}$ e porque unido a uma mulher não grega. A história de Medeia pressupõe, na velha tradiçãa ${ }^{(33)}$ e na leitura euripidiana do mito, um cruzamento de culturas e de sentimentos, que tem por fronteira as Simplégades ${ }^{(34)}$, primeiro ultrapassadas pelos Argonautas rumo a oriente, depois pela princesa da Cólquida, no sentido de ocidente. O que para os Gregos representava a conquista aventurosa de um tesouro - o velo de ouro - transformou-se para Medeia na conquista do coração de Jasão. Difíceis, ambos os objectivos e igualmente arriscados. O preço que Medeia teve de pagar, ainda na Cólquida, pela paixão que a devorava foi elevado. Apoiar Jasão e os seus objectivos equivaleu a trair os interesses do monarca local, e seu pai. Depois, para assegurar o êxito da fuga, a jovem raptou e trucidou o irmão, desviando as prioridades do monarca da perseguição dos fugitivos para a recolha dos destroços do cadáver do filho. Com o radicalismo destes actos, a jovem princesa tornou-se apátrida, 'apolis' no dizer de R. Friedrich $^{(35)}$, ou, se quisermos, estrangeira em relação aos seus.

Em nome da mesma paixão, Medeia veio para a Grécia, a caminho de um mundo evoluído, de que a fortaleza de Iolcos dá o primeiro sinal arquitectónico $(\mathrm{Med} .7)^{(36)}$. O que, no caso da Cólquida, é simplesmente 'terra' (v. 2) é, no da Grécia, cidade urbanizada. Mas mais do que uma diferença física que desde logo anuncia outro padrão de vida, foi sobretudo

(32) $\mathrm{O}$ chefe dos Argonautas era filho do soberano de Iolcos na Tessália, entretanto despojado do trono por seu irmão Pélias. Mas depois que Medeia preparou a morte do monarca usurpador, Jasão viu-se compelido, ele também, à situação de exilado.

(33) Sobre as versões anteriores do mito, que Eurípides remodelou de modo profundo e a que imprimiu um cariz definitivo e permanente até à modernidade, vide M. H. Rocha Pereira, Eurípides. Medeia (Coimbra, 1991), 10-12.

(34) Vide supra p. 191.

(35) 'Medea apolis: on Euripides' dramatization of the crisis of the polis', in Tragedy, comedy and the polis (Bari, 1993), 219-239.

(36) Aí Medeia cometeu novo crime ao convencer as filhas de Pélias a cozerem o pai numa poção mágica para recuperar a juventude, o que lhe impôs de novo a fuga desta vez para Corinto. Os crimes de Medeia ganhavam a configuração de aç̧ões contra as mais profundas relações familiares. A este episódio de Iolcos Eurípides dedicou a tragédia Pelíades. 
no plano do convívio social e humano que a exilada se ressentiu. A animosidade intuitiva contra o estranho, a que a Grécia também não era imune, é uma reacção que exige, da parte de quem procura integrar-se, cedência e esforço de adaptação, para além de um arrimo forte que lhe garanta um lugar no novo mundo. A Ama reconhece que Medeia tudo fez para agradar aos seus novos concidadãos, como a Jasão, seu marido, de quem dependia uma segurança que, neste caso, não é só a protecção da mulher casada na família, mas a da estrangeira na cidade (vv. 10-15). Com a quebra dos laços conjugais, Medeia deparou-se com uma reacção hostil, na cidade como na própria casa (v. 16). Jasão, por seu lado, abandonou um modelo de família que o inferiorizava para contrair outra aliança socialmente promissora: $o$ casamento com uma princesa - era-o também Medeia -, mas agora grega e filha da autoridade local. O que fora uma ligação coesa entre dois seres revelava-se nos seus verdadeiros fundamentos e desfechava numa divergência sem remédio: à paixão firme de um, correspondia a adesão calculista e cínica, mas nunca sentimentalmente comprometida do outro; a fragilidade e repúdio a que socialmente Medeia se via condenada era o preço a pagar pela promoção estável do Argonauta. Muito mais do que anseios de coração ou ciúmes de abandono, a alma exaltada que era por essência a de Medeia (vv. 20-22) vibrava de cólera, por um profundo sentimento de orgulho ferido associado ao temor da insegurança numa comunidade onde não tinha raízes.

A lembrança do passado, dos dias longínquos em que uma jovem se enleou de amores pelo comandante da nau Argo, enfatiza a fúria da heroína. Em nome de uma paixão imperativa, Medeia decidiu-se pelo exílio. Abandonou pátria e família, o mesmo é dizer posição e segurança, por alguém que o não merecia (vv. 30-33, 166-167, 255-258). E fê-lo de uma forma brutal, pela traição e pelo fratricídio, de modo que a sua partida produziu não só afastamento, mas ruptura e ódio em relação às suas raízes. O exílio tem no seu caso, pela violência de que se cercou, o carácter de uma partida sem retorno. Sonhar com o dia do regresso, que é sustento de alma para o exilado comum, está-lhe decisivamente interdito. Mas o que significa abandonar pátria e família foi o que Medeia veio a constatar, por seu mal tarde de mais (vv. 34-35, 462-463). Por isso o sentimento da ingratidão que a vitima é violento, agravado ainda pela agressividade de uma alma que se revela 'bárbara' no excesso e descontrole das suas manifestações (vv. 3845); 'bárbara' não porque não grega, mas porque demasiado espontânea, 
obediente a impulsos naturais, insubmissa a comedimentos ou à moderação que o nomos impõe (vv. 102-104). No entanto, é minha opinião na polémica que se instalou em volta do 'barbarismo' de Medeia ${ }^{(37)}$, que Eurípides não quis criar uma estrangeira exótica, enxertada como elemento estranho na sociedade grega - como será o caso do Frígio no Orestes - ou conferir-lhe os traços que contrastam o Grego com o Bárbaro, como no caso de Toas perante os filhos de Agamémnon. Medeia é uma mulher helenizada, que fez, como ela própria reconhece, uma aprendizagem da vida grega e um tremendo esforço de adaptação. Os agravos de que sofre e o desejo de vingança que alimenta são entendidos como legítimos por todos, antes de mais pelas Gregas que constituem o coro. Logo o que a conduz a extremos incompreensíveis e inaceitáveis - para perplexidade de quantos observam a congeminação do filicídio - não é a identidade não grega e um comportamento a ela inerente, mas a tendência para paixões extremas que em Eurípides é fisiológico na natureza feminina. Medeia figura, na produção do trágico, como modelo de um certo tipo de mulher e de comportamento feminino; e não, como é opinião de alguns, na galeria dos selvagens porque bárbaros.

A decisão de um novo exílio contra Medeia e os filhos, que a autoridade de Creonte determinou, faz estalar a tão temida crise. Pela segunda vez afastada dos seus, agora tendo por única companhia ódios, ressentimentos e temores, a heroína vibra de fúria e de desejo de vingança, numa solidão que a deixa imune à tentativa solidária de quem quer que seja de a desviar de intentos tão cruéis e em debate exclusivo com as suas próprias reticências. Antes de comentar as penas inerentes à condição feminina, Medeia valoriza aquilo que constitui a parte gravosa do seu caso, o estatuto de estrangeira. Em termos globais, refere-se a dike, a justiça, que não é qualidade natural no ser humano na avaliação do seu semelhante (vv. 219-221): 'É que a justiça não existe nos olhos dos mortais, quando sem mesmo se ter procurado conhecer com lucidez o âmago de uma criatura, se detesta, após um simples olhar, quem não pode ser acusado de qualquer injustiça'. E se esta leviandade é responsável por uma certa anarquia na valorização do semelhante, mais profunda é a animosidade quando a diferença cultural vem agravar as distâncias; aí um esforço de aproximação suplementar se impõe, de parte a parte, de modo a vencer preconceitos e a reduzir divergências (vv. 222224): 'Tem o estrangeiro por dever aproximar-se dos cidadãos. Mas não

(37) Vide R. Friedrich, op. cit., 220-224. 
aprovo também o natural de uma terra que, com sobranceria, atinge os seus conterrâneos por puro desconhecimento'. A xenofobia parece subjacente a estas palavras como uma reacção humana natural, contra a qual a inteligência e o coração devem reagir. Essas são as qualidades que o homem civilizado, grego ou não grego, tem ao seu dispor e que permitem a aproximação entre os seres humanos.

Da sua parte Medeia fez o exercício que se impunha para uma aprendizagem do que é viver na Grécia como estrangeira. Mas para além de ter de ceder e pactuar com costumes que não eram os seus, a mulher da Cólquida teve de fazer um outro esforço de aceitação de um modelo de vida conjugal, também ele estranho aos seus usos e personalidade. O papel que, na sociedade grega, estava destinado à mulher casada, de esposa submissa à vontade do marido e de mãe de família, com um comportamento discreto e apagado, muito mal assentava no espírito forte e determinado de Medeia. Fácil será de imaginar o esforço de apagamento a que teve de se submeter e a que preço. Só aquela determinação profunda ou até excessiva que punha em todos os seus actos lho terá permitido. Para verificar, perante a traição do pai dos seus filhos, que também esta cedência não tinha valido a pena. Nesse momento, a mesma determinação excessiva lhe ditou uma vingança, do seu ponto de vista equilibrada com o tamanho da ofensa. O plano de vingança que começa a germinar na mente de Medeia repercute, de alguma forma, a necessidade de iludir o inimigo. É como se, até certo ponto, o dolo que os exilados gregos convencionalmente preparam contra os poderosos bárbaros que os detêm, para garantirem o seu objectivo - a fuga e o regresso a casa -, se repetisse no plano inverso, o de uma exilada na Grécia que ensaia também o ludíbrio dos seus inimigos. Mas tudo é diverso na experiência de Medeia. A exilada não pretende a fuga, o regresso ou a salvação, que lhe estão vedados pela ruptura que os crimes do passado estabeleceram entre ela e a pátria a que pertencia. $\mathrm{O}$ seu alvo é tão só uma vingança contra o objecto do ódio que a destrói, Jasão, o traidor. Os sucessivos enganos com que ilude Creonte, arrancando-lhe a trégua de um só dia, Egeu, de quem obtém apoio e asilo incondicional, e até Jasão, que a julga rendida e submissa aos seus argumentos, são o trabalho da sua inteligência e determinação, mas também de uma finura muito feminina que vence, com a estratégia mais adequada, cada um dos actores masculinos do episódio que ensaia. Ingenuidade bárbara ou violência primária estão ausentes de um plano onde Medeia domina, por uma efectiva superioridade de espírito, cada adversário. 
Um primeiro diálogo inevitável, que tem de ser violento, se desencadeia entre Medeia e Jasão, onde cada um joga com os dados da sua personalidade: a estrangeira tormentosa e ressentida, mas frontal, o Grego mais controlado mas cínico e falso. Os deveres da philia são aí reivindicados por Medeia; outrora, na Cólquida, quando os perigos ameaçavam os aventureiros gregos e o êxito da missão, a salvação veio das suas mãos (vv. 476-482) e fez dela a verdadeira conquistadora do famigerado velo de ouro. Com uma ousadia natural posta ao serviço dos estrangeiros na sua terra, Medeia ousou ainda trair os seus e, já mais tarde, fomentar o assassínio de Pélias, numa atitude a que não faltou excesso e imprudência, como a própria reconhece (vv. 483-487). Mas pelo menos sobra-lhe o direito legítimo de pedir retribuição, 'a não ser que os deuses tenham perdido o seu poder, ou que leis novas imperem agora entre os homens' (vv. 493-494). Esta reivindicação denuncia mais uma vez o incumprimento, por parte de um grego, da retribuição devida a um gesto de philia, em que ao bárbaro coube a prioridade. Repete-se, em termos gerais, a acusação que Hécuba tinha podido fazer contra Ulisses, recordando o acolhimento amigo que lhe dera em Tróia e para o qual não encontra no momento a devida retribuição ${ }^{(38)}$. Tal como Agamémnon, na mesma peça dedicada à viúva de Príamo, assumia com arrogância a tradicional oposição Grego / Bárbaro para censurar a desumanidade de Polimestor, num contexto onde o comportamento grego está longe de ser modelar, da mesma forma Jasão regressa ao argumento para defender a satisfação da sua quota de retribuição devida à salvadora de outros tempos. Mesmo se vítima de abandono por parte de quem lhe devia apoio, Medeia ficou sempre a ganhar pelo facto de ter experimentado a civilização grega (vv. 534-541): 'Como contrapartida de me teres salvo, tu recebeste mais do que o que deste, como te posso provar. Antes de mais, a terra grega em vez de um território bárbaro tornou-se a tua morada; aprendeste a justiça e o recurso à lei, em vez da brutalidade. Todos os Gregos puderam conhecer a tua arte, o que te trouxe fama. Se tivesses permanecido nos confins do mundo, nunca ninguém teria ouvido falar de ti'. Mesmo se irónicas nos seus argumentos, as palavras de Jasão regressam ao critério tradicional na valorização da superioridade grega. A vantagem que a justiça e a lei proporcionam, condições que são de distinção entre barbárie e cultura, são por si uma experiência de vida compensadora. E mesmo os méritos

(38) Vide supra, p. 211. 
bárbaros, se existem, só através do reconhecimento e projecção no mundo civilizado ganham validade; no esquecimento e na distância de paisagens longínquas são como que inexistentes. Através da arrogância de Jasão, os Gregos afirmavam sem pejo o seu chauvinismo, não apenas como detentores de uma indiscutível superioridade, mas como uma espécie de árbitros universais dos méritos das restantes comunidades. Infelizmente para todos nós, argumento de uma tremenda modernidade. Porque cínicas na sua boca, as teorias repetidas por Jasão como elementares no convívio entre os povos mostram como a realidade é bem outra e o preconceito meramente artificioso. Só o respeito e o cumprimento efectivo dos princípios, não a sua recitação teórica, qualificam as comunidades humanas. Por isso é justa a acusação e a denúncia de Medeia (vv. 800-802): 'Cometi um erro, quando abandonei a casa paterna, iludida pelas palavras de um Grego'. Palavras que procuram preencher o vazio das regras e dos actos.

A conivência de uma alma apaixonada e fogosa com os ressentimentos que gera a tensão xenófoba de que Medeia se via rodeada desencadearam nela a mais violenta das reacções. Uma vingança cruel e excessiva impôs-se-lhe como a única saída capaz de lhe salvar a dignidade e de a salvaguardar do riso irónico dos espectadores da sua desgraça. A rival, atingiu-a com os filtros em que era hábil, que a reduziram a cinzas. Com ela pereceu o pai, esse Creonte que ousara proferir a sentença de exílio contra a vingadora. Jasão foi ferido com mais crueldade ainda através da morte dos filhos, um acto entre todos bárbaro 'que mulher grega jamais ousaria' (vv. 1339-1340), acusa o atingido. Mas o mito grego não lhe confirma a injúria. Realmente $o$ exemplo de uma Procne abona a verdade contrária. As Gregas são também capazes da barbaridade de um filicídio. Por isso, as palavras de Jasão revelam uma arrogância que é partilhada pela sociedade grega em geral. Medeia, além de estrangeira na terra de Corinto, foi-o sempre dentro da sua própria casa, no conceito do homem que amava. Logo a ofensa que ela vinga deixou de ser o amor traído, mas todas estas humilhações contra a sua condição de mulher, de princesa e de estrangeira de que nem mesmo o seu marido se mostrou isento. Não é também a natureza de uma bárbara primitiva e selvagem que a move; a mão que fere é a de uma mulher ressentida, a quem a energia natural não permite compromissos; da circunstância de ser estrangeira tira apenas mais um agravo a acrescentar a tantos outros.

Se Medeia representa a exilada que se empenha, mesmo se apenas com relativo sucesso, por se enquadrar na sociedade grega e por se helenizar nos 
comportamentos, Eurípides produz também o quadro do estrangeiro que exemplifica a importação directa e incólume de uma outra cultura para o mundo helénico. $\mathrm{O}$ seu Frígio, membro do séquito que Helena trouxe de Tróia, é o símbolo de um luxo oriental que não deixava de exercer fascínio sobre os Gregos amantes do requinte e do exótico que a Ásia proporcionava. É portanto o estranho assumido e, como tal, presente na sociedade grega com o estatuto servil que é próprio de um vencido de guerra. Como muitas casas de famílias abastadas ${ }^{(39)}$, em plena época clássica, o palácio de Argos no Orestes é a imagem de uma prosperidade que se pode permitir excessos sofisticados. Neste contexto, o bárbaro é o escravo de condição inferior, uma espécie de objecto de exibição criado à sombra de modelos orientais. Por entre as ameaças que pesam sobre uma casa reinante outrora poderosa, que parece caminhar para a ruína completa com a condenação dos seus últimos herdeiros - os filhos do grande Atrida, o vencedor de Tróia -, projecta-se, importado da Frígia, um estranho requinte, como o fulgor agressivo de uma jóia deslocada, em torno da própria responsável pela destruição dos dois povos, a bela Helena de Esparta. Do coquetismo vazio com que o poeta caracteriza a culpada da guerra faz parte a corte sofisticada em que se transformou o palácio argivo. A aparição e o testemunho do servo frígio são, dessa realidade, a prova evidente.

A estranheza desta personagem no quotidiano da Grécia repercute-se na novidade que a sua réplica teatral representa. $\mathrm{O}$ trajo e a linguagem, caudalosa e prolixa, sem uma delineação precisa que é própria do relato convencional de um mensageiro, conferem a esta figura traços de uma leitura cómica em retratos correspondentes ${ }^{(40)}$. Composto de modo a atrair sobre este estranho 'mensageiro' todas as atenções, o relato que ele vem fazer, sob forma de monódia, excede também tudo o que é a convenção própria deste modelo lírico. Não são os barbarismos de linguagem que marcam a diferença, mas a histeria expressa nos gritos selvagens, na prolixidade geral e nas repetições frequentes; todos estes elementos usados em dose elevada assentam bem na personagem, um servo de origem estrangeira tomado de um intenso pavor, que foge diante da espada ameaçadora de Orestes.

(39) Croally, op. cit., 113, lembra a atracção dos Atenienses pela exuberância dos trajos orientais (cf. Ps.-X. Ath. Pol. 2.8), sendo a sua cidade um grande centro de comércio onde se reuniam os produtos oriundos do império a que presidia e que confinava com as fronteiras do oriente asiático.

(40) Sobre a relação entre a convenção do mensageiro e o caso particular do Frígio, vide J. R. Porter, Studies in Euripides 'Orestes' (Leiden, 1994), 183-192. 
O exótico patenteia-se, desde logo, do exterior da figura, com os seus sapatos bárbaros (v. 1370; cf. A. Pers. 660), em corrida ligeira através de um palácio que não esconde o traçado dórico da sua arquitectura (vv. 1371-1372). E se o quadro exterior é paradoxal - o exotismo oriental transplantado para a sobriedade dórica -, não o é menos o requebro asiático que se espelha das salas e do tipo de vida adoptado pela senhora do palácio argivo (vv. 1426-1436). A velha Argos, por obra de Helena, transformou-se em inesperado harém asiático. À maneira frígia, um séquito rodeava a rainha, agitando-lhe em volta um leque circular de belas plumas. Por trás do cenário grego, revive a superioridade troiana no que respeita ao luxo do quotidiano, não apenas como simples memória de um passado de que só uma mancha de negro fumo escreve ainda o epitáfio; Tróia oferece-se agora como um quadro vivo que os vencedores transplantaram para paragens distantes. Em estranha conjugação, Helena entrega-se à tecelagem, tarefa paradigmática do dia-a-dia da mulher grega. Mas à tela com que pretende homenagear uma irmã que a guerra também vitimou junta púrpura, para obter um exótico tecido. Esta é obra natural nas mãos da filha do velho Tíndaro, que ela deseja, por evidente afinidade de gostos, fazer partilhar à irmã falecida.

Se o requinte efeminado que faz parte da tradição frígia não deixa indiferentes as mulheres gregas, o mesmo requebro asiático é objecto constante de crítica por parte do universo masculino da Hélade, composto pelos herdeiros do velho espírito guerreiro dos heróis de antanho. Não era inédita, no quadro que Eurípides reproduz do Bárbaro, a noção de que a cobardia que o caracteriza o coloca em posição de inferioridade no combate e o diminui perante o Grego. Os mesmos heróis, Orestes e Pílades, que agora intentam ocupar o palácio de Argos, já antes haviam enfrentado, na cena euripidiana, inimigos bárbaros. Na terra hostil dos Tauros, cercados de uma multidão de indígenas (IT 306, 316, 318-319), haviam posto à prova, numa situação limite, a sua superioridade. A desproporção evidente de forças é narrada por uma testemunha imparcial, um boieiro da região. Reduzidos à resistência dos seus braços, dois combatentes apenas perante uma multidão perigosa de Bárbaros, os Gregos rapidamente os puseram em fuga com um simples desembainhar de espada (vv. 323-324). E embora a desproporção numérica impossibilitasse a vitória final, não foi sem custo e à força de pedras lançadas à distância, numa estratégia cobarde de evitar uma luta corpo a corpo, que os bárbaros conseguiram por fim aprisioná-los (vv. 325-333). Do mesmo modo que, no termo da peça, no recontro 
final que opõe Tauros aos fugitivos helénicos, a vitória é ganha por Gregos pouco numerosos e desarmados, mas protegidos por uma capacidade física e atlética incomparável (vv. 1367-1371). Vantagem, desta vez bem sucedida, foi também a que Menelau conseguiu no Egipto contra uma horda de bárbaros, os marinheiros recrutados por Teoclímeno (Hel. 1593-1595). Mesmo se o efeito de surpresa valeu, neste caso, ao herói um ascendente, a superioridade grega ficou comprovada na resistência ao perseguidor e no sucesso da fuga (vv. 1595-1614).

Este traço bárbaro da inferioridade militar perante o Grego não depende só das armas adoptadas, mas sobretudo do carácter e da capacidade de reaç̧ão ao perigo. Assim os dois inimigos que Menelau terá de combater na sua própria casa - Orestes e Pílades - irão sem dúvida colocar-lhe dificuldades de que os Frígios em Tróia o desabituaram (Or. 1350-1352) ${ }^{(41)}$. A ideia de que os Frígios são cobardes, que é nova em relação à tradição épica, deve-se sem dúvida a um outro tipo de conhecimento do Bárbaro, quando a existência de escravos estrangeiros em abundância na cidade de Atenas muito veio contribuir para a depreciação dos diversos povos ${ }^{(42)}$. A imagem da cobardia frígia é, no Orestes, espectacular. Não se trata desta vez apenas de um relato de acontecimentos à distância, como acontece em Ifigénia entre os Tauros ou na Helena, nem tão pouco da visão de um campo aberto onde uma luta tem lugar. O cenário é doméstico, o palácio de Argos, os atacantes apenas dois, Orestes e Pílades, contra uma quantidade de servos frígios do palácio. A história começa pelo desfecho, a fuga emotiva e aparatosa de um bárbaro que entoa uma monódia exuberante ${ }^{(43)}$; ao mesmo tempo que se apresenta como uma figura efeminada em desespero - uma espécie de réplica caricatural das personagens femininas a quem geralmente são confiadas as monódias

${ }^{(41)}$ F. Chapouthier e L. Méridier, Euripide. Oreste (Paris, 1968), 86, chamam a atenção para o facto de esta acusação de cobardia dirigida contra os Troianos ser contrária à tradição épica. De facto, na Ilíada, os invadidos nada têm de cobarde (cf., e. g., 2. 862-863) e contam com o empenho de heróis que se medem, em valentia, com os campeões gregos, como é o caso de Heitor (Or. 1479-1480).

${ }^{(42)}$ Cf. E. Hall, op. cit., 101 e a afirmação sugestiva que faz de que, por esta época, 'livre' tornava-se definitivamente sinónimo de 'helénico' e 'servil' de 'bárbaro'.

${ }^{(43)}$ Tudo leva a crer que o requebro poético e musical da monódia do Frígio, com todo o seu anticonvencionalismo, venha na linha da revolução estética então operada sobre a música; Timóteo, um dos principais responsáveis por este processo reformador, na qualidade de autor de um ditirambo intitulado Persas, onde tonalidades frígias e persas estavam claramente expressas (cf. frs. 788-791 PMG), poderá ter sido uma boa fonte inspiradora para o autor do Orestes. Sobre esta questão, vide Porter, op. cit., 199-207. 
na tragédia de Eurípides -, o Frígio é também uma espécie de relator empenhado dos acontecimentos que viu e em que participou no interior do palácio. Sem reticências ou falsas justificações, confessa a cobardia que lhe põe asas nos pés e o lança numa fuga própria de um bárbaro. A histeria que o possui - o pólo oposto à brutalidade que também caracteriza o estrangeiro - explode em interjeições ${ }^{(44)}$ e repetições em que o canto monódico é por natureza abundante. Segue-se o relato dos factos que justificam esta reacção, ocorridos dentro do palácio. E não deixa de ser visivelmente irónica também a visão objectiva do que foi o comportamento dos Gregos, como o vê e relata um estrangeiro. Orestes e Pílades penetraram na mansão real, com funestas intenções de atentarem contra a vida de Helena. Cientes da presença da criadagem, de quem esperavam uma possível resistência, valeram-se do dolo para isolar a vítima. Se é certo que a atitude destemida dos príncipes gregos não passou despercebida ao Frígio (v. 1401), mais do que a valentia foi o talento e a habilidade que ponderaram. Sob o pretexto de uma súplica que tivesse por testemunhos os lares sacrossantos da casa, os dois invasores cercaram Helena e arrancaram-na do trono onde se demorava nos trabalhos de tecelagem, cercada de escravos. Ao dolo, os Frígios reagiram com pouca intuição (vv. 1416-1424). Hesitantes quanto ao sentido da cena que presenciavam, dividiram-se entre os que compreenderam o logro e os que dele não suspeitaram. Mas sobretudo não foram capazes de vencer o enleio da dúvida, tomados de susto diante da suspeita do perigo. Aproveitando da fraqueza visível desta reacção, Pílades sozinho - enquanto o comparsa se ocupava de Helena - pôde neutralizar-lhes o contra-ataque e simplesmente encarcerá-los nas dependências do palácio, com palavras de insulto à ineficácia bárbara (vv. 1446-1451). O próprio escravo reconhece que também neste episódio a inferioridade bárbara perante os Gregos foi manifesta (vv. 1483-1485). Assim repartidos, os Frígios perdiam o ascendente do colectivo e a única vantagem que lhes assistia, a do número. Entretanto os dois leões gregos $^{(45)}$ perseguiam a vítima, uma mulher indefesa, Helena. Só o seu grito,

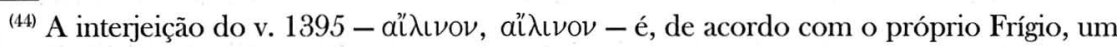
lamento bárbaro próprio do prelúdio de cantos fúnebres.

(45) Esta expressão, de inconfundível tonalidade homérica (cf. Il. 11. 324, 12. 42, 17. 282) torna-se profundamente irónica quando aplicada ao acto pouco heróico em que os dois agentes se encontram empenhados. Como bem comenta Ch. Wolff ('Orestes', in E. Segal, Oxford Readings in Greek Tragedy (Oxford, reimpr. 1991), 348), 'o que a perífrase poética aqui descreve é selvajaria irracional, aquilo que Tíndaro, ao referir-se a um padrão ilegal de vingança, tinha apelidado de 'bestialidade', to theriodes (524)'. 
anunciador do momento climático, foi capaz de decidir a hesitação bárbara, de forma inútil e tardia (vv. 1473 sqq.). A vantagem numérica foi mais uma vez aniquilada pela desordem e improviso da reacção, o que permitiu que, sozinho, Pílades fizesse frente à multidão frígia. Mas a vingança desejada não teve sucesso, porque o seu alvo, Helena, desapareceu por acção divina do alcance dos ódios humanos. Logo o radicalismo aparente da situação, que parece acentuar a superioridade militar e o sucesso dos Helenos, não resiste, no caso do Orestes, a uma análise um pouco mais atenta. Os novos heróis gregos, que constituem a descendência dos heróis de antanho, podem parecer ou julgar-se mais fortes do que escravos bárbaros; mas como cotejar os Aquiles, os Ájax ou os Atridas da tradição épica com esta nova vaga de guerreiros da Hélade, que se saem bem num recontro com um adversário cobarde ou com mulheres indefesas? Numa síntese feliz do que constitui, de ambas as partes, elemento de caricatura, escreve Porter ${ }^{(46)}$ : 'A constelação de dissonâncias e de incongruências que resultam da forma, da linguagem e da imagética, da proveniência, e do conteúdo do canto bizarro do Frígio sugeriram a muitos uma cena de troça de um pseudo-heroísmo homérico, dentro do qual a dita empresa gloriosa de Orestes e Pílades se revela como uma distorção perversa dos ideais heróicos que eles professam'.

Ao mesmo confronto, Eurípides dedica ainda um quadro final de expressividade iniludível. Tomado do calor do ataque, Orestes irrompe do palácio, de espada em punho, em perseguição de um único fugitivo, o Frígio, que sem hesitação nem resistência se lhe lança aos pés em prosternação súplice (vv. 1503-1507). A legendagem do quadro é implícita: em confronto de novo Grego e Bárbaro, homem livre e escravo, carrasco e vítima, herói e cobarde. Decerto com profunda ironia, Orestes elucida (v. 1508): 'Não estamos em Ílion; é em terra argiva que nos encontramos'. A leitura é óbvia, os heróis gregos dominam cobardes bárbaros em terras da Hélade. Mas Ílion é também o campo da arete de outros tempos, com que a Argos do momento perdeu todas as afinidades. Já não estamos em Ílion, são outros os tempos, será também uma interpretação conveniente ao curso posterior do diálogo. Aqui ou ali, num momento em que os ideais elevados ruíram, tanto faz. A regra em vigor é salvar a pele e pôr sempre a vida à frente da morte (vv. 1509, 1523). O Frígio doutrina com pragmatismo sobre este objectivo tão anti-heróico e anti-militar, mas salvador em qualquer

(46) Op. cit., 177. 
parte do mundo. Por ser mesquinho e baixo, não deixa de ser autêntico e popular neste final de séc. V. O próprio Orestes, condenado à morte pela assembleia argiva, não decidiu, com a conivência de Pílades e de Electra, depois de um relâmpago de heroicidade passageira perante a condenação, simplesmente matar Helena e raptar Hermíone em nome exclusivo da salvação? $\mathrm{O}$ desamparo aflito que o Frígio exibe com despudor devolve a imagem da angústia do próprio herói, cuidadosamente montada ao longo de toda a peça. De repente, as cores do quadro mudam de tom. Armados da lança dos fortes ou da cobardia dos fracos, todos os homens defendem um mesmo objectivo: salvar a pele. Reconhecê-lo é, da parte do Frígio, uma mostra de clarividência sobre o que seja, para além de todos os heroísmos, a verdade da condição humana. Orestes tem também a frontalidade de o confirmar, quando, depois de assegurada a neutralidade e submissão do inimigo, se limita a concluir com um misto de empatia e sarcasmo (v. 1524): 'Tens razão. É teres disso consciência que te salva' ${ }^{(47)}$. No plano da acção, a regra redentora é a cobardia, que poupa o Frígio da ameaça do golpe do herói, e que poupa também o herói, desviando-o de uma morte gloriosa para o caminho de uma dúbia salvação.

Já em termo de carreira, Eurípides repunha a temática dos cruzamentos culturais, agora com uma tonalidade diferente. Trata-se ainda, em Bacantes, de trazer ao convívio do mundo grego a presença do estrangeiro, não mais através de uma personalidade individual e concreta que tenta helenizar-se ou, pelo contrário, se impõe com todo o exotismo de uma importação que se quer conservada nos seus traços originais; o estrangeiro é, desta vez, um colectivo, que representa uma cultura estranha expressa em rituais desconhecidos, e que força, sem tolerância, a sua aceitação pelo mundo grego $^{(48)}$. O choque de culturas é desenhado dentro de um espaço geográfico

${ }^{(47)}$ Orestes repete agora a famosa palavra synesis, que usara (vv. 395 sqq.) para o seu próprio reconhecimento do acto horrendo que tinha cometido, o matricídio, o que evidencia alguma afinidade entre o filho de Agamémnon e a sua vítima do momento, o Frígio. Sobre o sentido

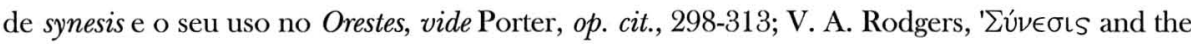
expression of conscience', GRBS 10 (1969), 241-254; J. Assael, '¿úveðıs dans Oreste d'Euripide', Ant. Clas. 65 (1996), 53-69.

${ }^{(48)}$ E. Hall (op. cit., 151 sq.) lembra, em oposição à origem estrangeira ou mesmo tardia do ritual báquico na Grécia aqui defendida, que o culto dionisíaco é muito antigo e popular no mundo grego. Representado com uma enorme vitalidade cívica na Atenas do séc. V, foi aí sentido como uma velha tradição. A confusão surgida em torno desta matéria, que transparece dos testemunhos da própria antiguidade, parece significar que o culto dionisíaco na Grécia sofreu influências inovadoras vindas de fora; uma existência já longa e a dispersão por um espaço amplo 
de grande amplitude e tem a força de uma concepção cultural no abstracto, que se impõe apesar de todos os conflitos, dúvidas ou rejeições. É Dioniso o inspirador desse estranho culto e o primeiro factor de uma tremenda ambiguidade, porque associa, na tradição da sua origem, elementos de identidade genuinamente grega com outros asiáticos. Antes de mais, dentro da apresentação devida na abertura da peça, Dioniso afirma a proveniência tebana, como filho de Sémele de regresso à terra natal (vv. 1-3), provindo do oriente. Mas, mais tarde, Penteu vai dirigir-se-lhe como a um estrangeiro oriundo da Lídia (vv. 233-234) e o próprio deus reafirma esta origem, quando aprisionado às ordens do soberano (vv. 460-464). Todavia o que parece ser distância e separação efectiva entre estes dois espaços conhece desde logo uma aproximação. Não é nova para Tebas a presença oriental, que traz uma intervenção profunda na existência da cidade. $O$ próprio fundador lendário de Tebas, Cadmo, era um fenício (vv. 10-11) que um dia, chegado de Sídon, lançou os fundamentos civilizacionais da velha urbe com a construção de uma fortaleza que passou a definir-lhe as fronteiras (vv. 171-172). Nas suas raízes mais remotas há um germe importado da Ásia, que é patente à consciência grega, de uma permeabilidade de culturas na história mais antiga do Mediterrâneo oriental.

Por isso a chegada de um culto trazido pela mão de Dioniso, o filho de uma tebana, com todas as características orientais que o definem, não é, pela origem, uma excrescência absoluta dentro de uma cultura pura e ilesa de infiltrações. Não reside aí, portanto, o motivo exclusivo da rejeição, mas nas práticas agressivas e contrastantes com a convenção social helénica que nele dominam. Estas podem ser, em Penteu, que personaliza a oposição radical ao deus, razões pessoais, traduzíveis de uma forma linear: tudo o que lhe parece estranho ou novo cria nele resistência e rejeição. Mas é óbvio que, da escala pessoal, esta atitude pode evoluir para a expressão de uma reacção humana natural e universal.

proporcionaram a interpenetração de outros cultos. Interessante é também a observação que Th. Rosenmeyer ('Tragedy and religion', in E. Segal, Oxford Readings in Greek Tragedy (Cambridge, 1994), 374) faz sobre a mesma matéria: dadas as características próprias do culto tradicionalmente grego de Dioniso - como uma espécie de emblema do que é a vida humana nas suas componentes mais cruas -, seria uma medida cautelar, para preservar a reserva característica do espírito grego, considerá-lo, nos seus excessos, como um produto importado, de origem estranha. Daí que o Grego do séc. V tenha sobre Dioniso uma crença ambígua: embora considerado estrangeiro de proveniência, era venerado como um membro póderoso do panteão olímpico. Sobre a antiguidade de Dioniso, vide ainda M. H. Rocha Pereira, Eurípides. As Bacantes (Lisboa, 1992), 11. 
O deus refere ainda, de passagem (vv. 21-22), 'as danças e os rituais' que exprimem a sua presença e o culto que lhe é devido. Por insígnias os fiéis usam a nébride e o tirso, ornamentado de folhas de hera (vv. 24-25, 79-81); e logo o recorte do culto se vai precisando: na peugada do deus, a multidão feminina ergue os tamboretes, instrumentos da Frígia, que Reia, a Deusa Mãe, inventou, como frígios são também, naturalmente, os sons que produzem (vv. 55-59). Com a entrada do coro de Bacantes que, desde os montes frígios, segue Dioniso, a descrição transforma-se em imagem e som; referem-se as coroas de hera e os ramos de carvalho ou de pinheiro; tufos de lã e peles de animais revestem as mulheres, que agitam nas mãos, com piedade profunda, os tirsos sagrados (vv. 105-119, 702-703). A multidão freme ao som das percussões cretenses, combinadas com a melodia flexível das flautas orientais, num transe frenético (vv. 120-133, 155-165). Da distância, a memória traz a visão agitada do ritual (vv. 135-167). O cenário são as montanhas, da Lídia e da Frígia, como remissão obrigatória para um paradigma que se quer expandir e retomar em paisagens semelhantes, num espaço que se promete no futuro universal. Os movimentos são frenéticos, a corrida desenfreada que termina num espojar-se no solo; a ela se mistura a perseguição dos animais, que desfecha no desmembrar da caça e no devorar sangrento da carne crua (vv. 734-745). Presente, o deus actua à frente do exército feminino, fazendo ouvir uma voz de comando que soa no grito evoé. Do solo, por obra divina, brotam leite, vinho e mel (vv. 704-711). As tochas acesas que se brandem com braço poderoso chamam as servas desgarradas. Todo o quadro se cobre de um vapor de incenso da Síria, ao som estimulante de tamboretes e flautas. Tudo, neste ritual, é distante e estranho à justa medida indispensável à sophrosyne grega. Longínqua a paisagem, surpreendente a agitação e histeria do rito, como a desordem espontânea e natural de cada gesto ou acto. Estrangeiros são também os sons que acompanham esta imagem sagrada, brados frígios e revoltas melodias asiáticas. Ainda que o deus que tudo move e ordena seja o filho de uma tebana.

Para além de asiático nos excessos que permite, o ritual dionisíaco comporta uma espontaneidade e um contacto imediato com o que é dádiva da natureza, que faz dele uma experiência ansiada por todo o ser humano. Este reconhecimento do carácter fisiológico do rito, que o torna humano na sua naturalidade essencial, traz à noção de barbarismo que se lhe aponta uma correç̧ão. A selvajaria que o caracteriza não é o fruto de uma origem 
asiática, que se opõe ao cenário grego de Bacantes - o mundo da rejeição do culto -, mas sobretudo o resultado da explosão da physis humana reprimida pelo poder social dos diferentes nomoi. Esta mesma noção tem a chancela do próprio Dioniso, como se torna claro do diálogo que o deus mantém com Penteu, onde tenta ainda elucidá-lo sobre a verdade profunda do culto que representa (vv. 482-484): 'Dioniso - Todos os Bárbaros celebram os seus mistérios. - Penteu - Sim, porque esse é um aspecto em que são muito menos esclarecidos do que os Gregos. - Dioniso - Pelo contrário, são bem mais esclarecidos, embora os seus costumes sejam diferentes'.

Neste aspecto essencial do culto reside o seu potencial de universalidade, que se exprime pela propagação sem limites a que tem direito. Dioniso recorda (vv. 13-20) o percurso que o seu ritual já venceu desde a Lídia natal, por toda a Ásia, que é retratada com os atributos de riqueza, de arquitectura, de paisagem e de clima que lhe são convencionais. Iniciaram-no os campos férteis em ouro da Lídia; receberam-no depois as planícies frígias, os planaltos queimados de sol da Pérsia, as fortalezas da Bactriana, o terreno glacial da Média, a prosperidade da Arábia, antes de o terem acolhido também os Gregos, aqueles que nas cidades costeiras da Ásia Menor convivem com o Bárbaro, numa mescla inevitável. Toda a Ásia, portanto, se rendeu ao poder imbatível de Dioniso, o mesmo é dizer, foi a primeira a reconhecer e a aceitar a força espontânea da natureza humana e a dar-lhe desafogo, colectivo e sagrado. E o deus não hesita em anunciar que agora é a Grécia - como um passo inicial em território europeu - a conhecer-lhe a expressão (vv. 23-25). Em Tebas, onde o primeiro recontro de nomoi entre oriente e ocidente ocorre, se prevê já o choque terrível que se prepara. Penteu, o rei local e o garante de um outro nomos, mostrou a animosidade que alimenta pelo ritual, como por tudo aquilo que signifique ameaça à ordem cultural de que a autoridade instituída é símbolo. A reacção do monarca não deixa de ter também uma expressão individual, própria do que é a personalidade constante de um tirano. A sua reacção será, por isso, a de alguém que vê a autoridade que detém confrontada e batida por um poder estrangeiro que inesperadamente chega aos seus domínios (vv. 233-234). Este é um motivo de natureza política que faz todo o sentido em Penteu como monarca, como em todos os poderes ditatoriais e xenófobos de que, em certa medida, ele pode ser o paradigma. Ao mesmo tempo que resiste ao culto asiático, o monarca renega a própria physis, num esforço determinado para a sufocar nas suas manifestações espontâneas, em nome de uma ordem convencional 
de que a comunidade tebana é exemplo. Penteu não entende que Dioniso é o criador de uma nova ordem, que traz à humanidade prazer e paz (vv. 416-419). Esse objectivo o deus alcança-o não pela pressão da regra social, mas pelo efeito libertador do vinho, que estimula a natureza humana a conhecer-se e a atingir a sua própria realização e depuração. O que constitui, porém, a ordem convencional do mundo, que se criou por obra dos artifícios engenhados pelo espírito dos homens, repugna a Dioniso; é esta verdade que o coro afirma com clareza (vv. 424-431): 'O deus abomina aquele cujo empenho não está em, sob a luz do dia ou na suavidade da noite, disfrutar o prazer da vida. Sábio é quem sabe manter a alma e o espírito longe do engenho arrogante dos homens'. Aqui reside exactamente o erro de Penteu. À imposição da vontade divina, o rei de Tebas contrapõe o desejo de fazer prevalecer o seu próprio nomos, repudiando sem análise tudo o que é novo em favor do seu conceito do que é ordem, condição feminina, equilíbrio familiar ou preconceito nacionalista. E talvez a sua posição radical vise, em última análise, um objectivo medíocre: o de defender a sua própria posição e segurança à frente da polis, mais do que preservar Tebas de um perigo, cuja medida não perde sequer tempo a avaliar. Enfim, a derrota de Penteu não o converte num mártir, mas na vítima de uma falta perigosa de clarividência. É esta resistência que provoca a explosão que custa a vida ao soberano e à sua cidade a invasão forçada do novo culto. Porque a vida tem a capacidade de explodir de sob os limites estreitos do quotidiano e de rebentar com o artificiosismo das convenções sociais.

Da sua vitória Dioniso não deixa dúvidas, nem tão pouco do prosseguimento da sua campanha que tem por limites o universo (vv. 48-50): ' $\mathrm{E}$ depois de aqui, nesta terra, ter estabelecido a ordem devida, por me ter dado a conhecer, encaminharei os meus passos para outro destino'. A cruzada de Dioniso é paradoxalmente interior e exterior a uma só vez, porque o que chega da Ásia é apenas a repercussão exterior, sob forma de um rito estranho, de uma experiência intrínseca à natureza humana. Com os olhos postos na realidade política e social do séc. V helénico, Tucídides (3. 84. 2) traduziu, em termos de uma civilização que vive uma crise decisiva, questão idêntica à que Eurípides, com tão estranha versão, traz à cena nas Bacantes: 'Na confusão em que se transformou a vida nas cidades, a natureza humana, sempre rebelde contra os nomoi e agora no seu controle, revelou-se alegremente descontrolada sob o efeito da paixão, acima do respeito pela justiça e avessa a toda e qualquer autoridade'. 
Da leitura global da problemática do Bárbaro em contraste com o Grego no teatro de Eurípides resulta o quadro pleno das nuances, que nesta matéria a Grécia experimentava depois dos acontecimentos da sua história recente. A ideia tradicional de uma dicotomia profunda entre Grego e Bárbaro, o mesmo é dizer, progresso e atraso, civismo e selvajaria, separados pelo limite nítido de uma fronteira geográfica, que resultava do contencioso bélico entre ocidente e oriente como o tinha vivido a Grécia, perdia sentido. Porque já um outro conflito, desta vez inteiramente para cá de uma linha de fronteira, a guerra entre Gregos e Gregos, o punha em questão. Progresso e atraso, civismo e selvajaria passaram a definir-se por outros mecanismos de separação: os que se orientam pelos princípios e pela observância dos comportamentos correctos. A ideia do Grego / barbarizado e do Bárbaro / civilizado subverteu toda a lógica anterior e criou uma nova ordem, universalista e sem fronteiras. Talvez desta concepção de progresso Bacantes retratem uma última etapa: aquela em que a noção de civismo e de barbárie se traduz em termos de nomos e physis, para reconhecer que são ténues as diferenças entre os homens, todos eles naturalmente irmanados por uma mesma massa essencial. Só os nomoi, a convenção ou ordem social, cujo peso os sofistas se não cansaram de questionar, podem acentuar as divergências. Distinção que é superficial e contra natura. Insistir-lhe na legitimidade pode ser simplesmente uma atitude irracional, que traz, a quem nela persiste, uma derrota atroz e sem limites.

\section{Bibliografia}

M. ARThuR - 'The choral odes of the Bacchae of Euripides', YClS 22 (1972), 145-179.

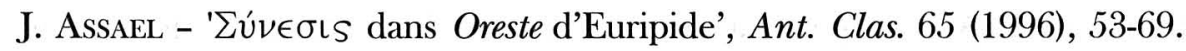

R. Buxton - 'Iphigénie au bord de la mer', Pallas 38 (1992), 209-215.

N. T. Croally - Euripidean polemic. The Trojan women and the function of tragedy (Cambridge, 1994).

M. J. Cropp - Euripides. Iphigeneia in Tauris (Warminster, 2000).

H. Diller - 'Euripides' final phase: the Bacchae', in E. Segal, Oxford Readings in Greek Tragedy (Cambridge, 1994), 357-369.

R. Friedrich - 'Medea apolis: on Euripides' dramatization of the crisis of the polis', in Tragedy, comedy and the polis (Bari, 1993), 219-239. 


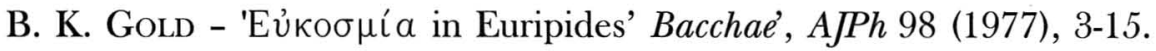

E. HALL - Inventing the barbarian. Greek self-definition through tragedy (Oxford, 1989).

K. V. Hartigan - 'Salvation via deceit: a new look at the Iphigeneia at Tauris', Eranos 84 (1986), 119-125.

B. M. W. Knox - 'The Medea of Euripides', in E. Segal, Oxford Readings in Greek Tragedy (Cambridge, 1994), 272-293.

D. Kovacs - The heroic muse (Baltimore, 1987).

E. LÉvy - 'Naissance du concept de barbare', Ktema 9 (1984), 5-14.

A. J. Podlecki - 'Individual and group in Euripides' Bacchae', Ant. Clas. 43 (1974), 143-165.

J. R. PORTER - Studies in Euripides' Orestes (Leiden, 1994).

M. O. Pulquério - 'Um testemunho ideológico: As Bacantes de Eurípides', Humanitas 39-40 (1987-1988), 25-41.

Ra'anana Meridor - 'The function of Polymestor' s crime in the 'Hecuba' of Euripides', Eranos 81 (1983), 13-20.

M. H. Rocha Pereira - Eurípides. As Bacantes (Lisboa, 1992).

V. A. Rodgers - ' $\sum v \dot{v} \in \sigma \iota s$ and the expression of conscience', GRBS 10 (1969), 241-254.

Th. Rosenmeyer - 'Tragedy and religion', in E. Segal, Oxford Readings in Greek Tragedy (Cambridge, 1994), 370-389.

S. SAID - 'Grecs et barbares dans les tragédies d'Euripide. La fin des différences?’, Ktema 9 (1984), 27-53.

P. Schubert - 'L'Hécube d'Euripide et la définition de l' étranger', QUCC 64. (2000), 87-100.

Ch. Segal - 'Violence and the other: Greek, female and barbarian in Euripides' Hecuba', TAPhA 120 (1990), 109-131.

M. F. Silva - 'Elementos visuais e pictóricos na tragédia de Eurípides', Humanitas 37-38 (1986), 9-86.

R. G. Ussher - 'The Cyclops of Euripides', GE्ER 18 (1971), 166-179.

V. Visa-Ondarçuhu - 'Le Cyclope d'Euripide ou la mise en scène de nouveaux espaces', Pallas 54 (2000), 61-79.

CH. Wolff - 'Orestes', in E. Segal, Oxford Readings in Greek Tragedy (Cambridge, 1994), 340-356. 


\section{Série}

\section{Documentos}

Imprensa da Universidade de Coimbra

Coimbra University Press

2005

- U

C - 